\title{
Vegetational and agricultural dynamics at Burgäschisee (Swiss Plateau) recorded for 18,700 years by multi-proxy evidence from partly varved sediments
}

\author{
Fabian Rey ${ }^{1,2}$, Erika Gobet ${ }^{1,2}$, Jacqueline F. N. van Leeuwen ${ }^{1,2}$, Adrian Gilli ${ }^{3}$, Ulrike J. van Raden ${ }^{3}$, \\ Albert Hafner ${ }^{2,4}$, Othmar Wey ${ }^{2,4}$, Julia Rhiner ${ }^{1}$, Daniela Schmocker ${ }^{1}$, Jan Zünd ${ }^{1}$, Willy Tinner ${ }^{1,2}$ \\ ${ }^{1}$ Institute of Plant Sciences, University of Bern, Altenbergrain 21, 3013 Bern, Switzerland \\ ${ }^{2}$ Oeschger Centre for Climate Change Research, University of Bern, Falkenplatz 16, 3012 Bern, \\ Switzerland \\ ${ }^{3}$ Geological Institute, ETH Zurich, Sonneggstrasse 5, 8092 Zurich, Switzerland \\ ${ }^{4}$ Institute of Archaeological Sciences, University of Bern, Muesmattstrasse 27, 3012 Bern, Switzerland
}

Corresponding author: Fabian Rey, fabian.rey@ips.unibe.ch, +41 316314922

\section{Acknowledgments}

We thank Willi Tanner, Richard Niederreiter, André F. Lotter, Claire Rambeau, Marianne Steffen, Camilla Calò, Stéphanie Samartin, Elisa Vescovi, Stefanie Wirth, Stewart Bishop and Martin Tschanz for their help during the fieldwork, Florencia Oberli for her help in the laboratory and during the corings, Flavio S. Anselmetti for his support as well as the two reviewers for their valuable suggestions on the manuscript. This study was funded by the Swiss National Science Foundation (SNF 200021_149203/1 and PMPDP2-122945). 


\section{Abstract}

Little is known about the timing and the vegetation dynamics shortly after the Last Glacial Maximum (LGM) on the Swiss Plateau 19,000-15,000 cal B.P. Subsequent Late Glacial and Holocene vegetation changes are better known; however, it is unclear if the few available palynological and macrofossil records are able to capture the entire vegetation variability of the region. A new palaeoecological multiproxy study using pollen, spores, charcoal and X-ray fluorescence (XRF) from Burgäschisee (Swiss Plateau, $465 \mathrm{~m}$ a.s.l.) is used to reconstruct vegetation, fire and land use for the past 19,000 cal. years. Steppe tundra vegetation established at c. 18,700 cal B.P. only c. 300 years after the end of the LGM and deglaciation. A shift from steppe tundra (Artemisia, Helianthemum) to shrub tundra (Betula nana, Salix, Juniperus) with sporadic tree Betula stands occurred around 16,000 cal B.P., most likely in response to climate warming after the end of Heinrich event 1. Abundant spores of coprophilous fungi (Sporormiella, Cercophora) may reflect the presence of Pleistocene large herbivores (e.g. Mammuthus primigenius, Bison bonasus, Rangifer tarandus). Afforestation started more than 2,000 years later with Juniperus and tree Betula around 14,500 cal B.P. Mixed Betula and Pinus sylvestris forests persisted until the onset of the Holocene at 10,800 cal B.P., when mixed elm forests expanded into the region in response to climate warming. Around 8,200 cal B.P., mesophilous Fagus sylvatica and Abies alba partly replaced more heliophilous species in the forests, when climate became less continental and more moist. Pollen of Cerealia, Plantago lanceolata and other crops and weeds suggest that agricultural activities became significant during the Neolithic around 6,500 cal B.P. (4,550 cal B.C.). Archaeological findings from Neolithic pile dwellings around 5,950 cal B.P. (4,000 cal B.C.) indicate local settlements around the lake. The lake sediments are laminated for most of the last c. 6,800 years. With two independent proxies (XRF and pollen), we can demonstrate that these laminations are annual, suggesting short-term mixing of the lake water due to a more open landscape in response to land use. Our study shows that the annually laminated (varved) sediments from Burgäschisee have a great potential for high resolution multi-proxy analyses covering the past c. 6,800 years. They can provide accurate ages of cultural phases that might be compared with dendro-chronologically dated evidence from lake dwellings.

Keywords: Vegetation history, Fire history, Varves, LGM, Heinrich event 1, Human impact 


\section{Introduction}

The Swiss Plateau is a densely populated area that stretches from Lake Constance in the East to Lake Geneva in the West. It forms a complex mosaic of forests, agricultural lands, lakes, rivers and settlements. This lowland region with its rather favourable climate for agriculture is also at the origin of first Neolithic farming societies in Switzerland with more or less permanent settlements. Many archaeological findings across the whole Swiss Plateau show that it has been consecutively populated ever since (Hafner and Suter 2003; Stöckli 2016), emphasizing the importance of the lowlands for past civilizations.

Palaeobotanical and palaeoecological studies on the Swiss Plateau have a long tradition (e.g. Welten 1946; Ammann 1989; Lotter 1999; Wehrli et al. 2007). Many of these studies focused on the Late Glacial environmental history (e.g. Ammann and Tobolski 1983; Ammann et al. 1994) but also the Holocene has been intensely investigated (e.g. Ammann et al. 1996; Haas and Hadorn 1998; Tinner and Lotter 2006; Gobet et al. 2016). The temporal evolution of the vegetation in the Late Glacial and the Holocene is well established for the Swiss Plateau (Ammann and Lotter 1989; Lotter 1999; Wehrli et al. 2007). However, the timing and onset of the deglaciation and the initial vegetation development north of the Alps is still unclear (Eicher 1987). In the Southern Alps and their forelands Juniperus shrublands (pollen, stomata finds) established c. $18,000-17,500 \mathrm{cal}$ B.P. in the formerly glaciated areas, c. 3,000 years before a similar expansion occurred north of the Alps (Vescovi et al.2007). Similarly, afforestation in the Southern Alps and their forelands preceded that in the Northern Alps and the Swiss Plateau by about 2,000 years (e.g. Vescovi et al. 2007; Pini et al. 2016). While north of the Alps forest vegetation established in response to the Bølling warming, south of the Alps similar vegetation dynamics were caused by warming after Heinrich event 1 (Samartin et al. 2012). We assume that pre-Bølling warming (e.g. at 18,000-17,000 and 16,500-16,000 cal B.P.) also had an impact on the vegetation north of the Alps, but this issue has not been investigated so far.

Burgäschisee lake sediments are an exceptional archive in Central Europe covering more than 18,700 years of vegetation history including most of the settlement phases during the last c. 6,800 years. In the 1940s, the site was palynologically investigated by Max Welten, resulting in a more than 15,000 years long vegetation reconstruction (Welten 1946). The lake shore settlements were investigated 
intensively in the middle of the last century including an on-site palynological transect through one of

the settlements (Welten 1955, 1967).

Annually laminated sediments are rare (Geyh et al. 1971; Zolitschka 1998; Swierczynski et al. 2013). For the Swiss Plateau, only very few annually laminated sediment sequences are known and the laminated parts usually end before the onset of the Neolithic or cover only the last few decades (Welten 1944; Lotter 1999; Monchamp et al. 2016). New subaquatic coring devices allowed for the coring of the deep centre of Burgäschisee offering the unique opportunity to retrieve sediments with annual layers and to therefore investigate human impact with high chronological precision and resolution. In this study we present a modern multi-proxy environmental reconstruction from Burgäschisee on the Swiss Plateau. The aims of the study are (1) to better understand the deglaciation timing and the vegetation dynamics during the Oldest Dryas $(19,000-15,000$ cal B.P.), (2) to compare the vegetation and fire history of the last 19,000 years with other lowland sites north and south of the Alps to provide novel well-dated information, and (3) to prove the annual structure of the sediments with pollen and XRF data.

\section{Study Site}

Burgäschisee is a small eutrophic lake at $465 \mathrm{~m}$ a.s.l. $\left(47^{\circ} 10^{\prime} 8.5^{\prime \prime} \mathrm{N}, 7^{\circ} 40^{\prime} 5.9^{\prime \prime} \mathrm{E}\right)$ on the Swiss Plateau which geologically belongs to the generally carbonatic-rich molasse region with abundant sandstones between the Jura mountains and the Alps (Schmid et al 2004, Fig. 1). The lake is named after the village Burgäschi which is located at the northwestern lake shore. It has a surface area of 21 ha, a maximum water depth of $31 \mathrm{~m}$ and a hydrological catchment area of 319 ha (Guthruf et al. 1999). Four small inflows feed the lake in the southwest and one outflow leaves the lake in the north (Müller-Beck 2005a). In 1943, the lake level was lowered by up to $2 \mathrm{~m}$ to drain the wetlands in the surroundings and create agricultural land (Arn 1945). Since 1977, deep water is mixed with oxygen to improve water quality (Ambühl and Stumm 1984). The climate at Burgäschisee is oceanic. The mean annual temperature is $9.1^{\circ} \mathrm{C}$ and the annual rainfall average out at $1088 \mathrm{~mm}$ (data from Koppigen c. $6 \mathrm{~km}$ from Burgäschisee, (C) MeteoSchweiz). The warmest month is July with a mean temperature of $18.6{ }^{\circ} \mathrm{C}$ and the wettest months are Mai-August with more than $100 \mathrm{~mm}$ of precipitation per month. 
Black alder (Alnus glutinosa) and common ash (Fraxinus excelsior) grow along the lake shores.

Mixed beech (Fagus sylvatica) forests are dominant on the more elevated surroundings. The rest of the landscape is intensively shaped by agricultural activities. The lake, the shores and the wetlands around (e.g. Chlöpfimoos) are under nature protection and are partly used for leisure activities. About 18,500 years ago, the lake surface was c. six times larger than today (von Burg et al. 2011). Several findings from hunter camps located along the former lake shores (e.g. Fürsteiner) can be attributed to the Magdalenian and the Late Palaeolithic c. $18,500-11,600$ cal B.P. (16,550-9,650 cal. B.C., Wyss 1952; von Burg et al. 2011). Also Mesolithic sites from hunter and gatherers are known in the region (Wyss 1953). First main archaeological excavation activities started in 1877 and 1902 . After the lake level lowering in 1943, wooden piles from Neolithic settlements emerged. All of them were partly excavated in the middle of the last century (Müller-Beck 2005b; Wey 2012). New excavations devoted to the recovery of material culture and wood for dendrochronological dating are currently running at Burgäschisee within the interdisciplinary project "Beyond Lake Villages" (Swiss National Science Foundation, CR20I1L_152862). So far, at least five settlements sites are known from Burgäschisee. One of these sites ("Burgäschisee-Ost") is part of the UNESCO World Heritage "Prehistoric pile dwellings around the Alps". Early and Middle Bronze Age archaeological findings are rare, however, Late Bronze Age settlements point to more human activity in the region (Hodel et al. 2011). From the Iron Age on until today, the Burgäschisee region has always been occupied as shown by many finds, including Iron Age and Roman artifacts at the nearby Inkwilersee, a Roman storage building close to Burgäschisee and the remains of a church from the Early Middle Ages (Hodel et al. 2011; Marti 2011).

\section{Materials and methods}

\section{Seismic survey and coring}

A high-resolution $(3.5 \mathrm{kHz})$ reflection seismic survey was performed in July 2009 to find the most suitable spot for coring (avoidance of subaquatic landslides) and to understand the topographic structure of the lake basin (Fig. 1). In September 2009, three parallel sediment cores (Burg A-C) reaching a coring depth of $15 \mathrm{~m}$ were retrieved with an UWITEC piston corer with a diameter of $60 \mathrm{~mm}$ at the deepest 
part of the lake. Since it was not possible to create a complete composite sediment core, a second coring campaign was successfully performed in April 2014 to fill the gap (Burg I).

\section{Chronology}

Sixteen radiocarbon dates on terrestrial plant macrofossils (Table 1), the Laacher See Tephra (LST) at $806.5 \mathrm{~cm}$ and the sediment surface (year 2009) were used for the age-depth model. The radiocarbon content of terrestrial plant remains was measured at the Laboratory of Ion Beam Physics at ETH Zurich, the Poznan Radiocarbon Laboratory and the Laboratory for the Analysis of Radiocarbon at Bern University using accelerator-mass-spectronomy (AMS). The radiocarbon dates were calibrated with the program Calib 7.1 (Stuiver and Reimer 1993) using the IntCal13 calibration curve (Reimer et al. 2013). A smooth-spline curve (smooth 0.23) was calculated with the program clam 2.2 (Blaauw 2010) to assess the definite age-depth model (Fig. 2). The modelled curve runs within the $2 \sigma$ error range of the calibrated radiocarbon ages and the $2 \sigma$ confidence envelope of a generalized mixed-effect regression that includes sample depth and age uncertainties (Birks and Heegaard 2003; Heegaard et al. 2005).

\section{XRF and LOI analyses}

XRF core scanning with an Avaatech core scanner was performed in continuous $1 \mathrm{~mm}$ resolution. An area of $1 \mathrm{~mm}$ down-core and $12 \mathrm{~mm}$ cross-core was measured for 20 seconds per measurement with 10 $\mathrm{kV}(1500 \mu \mathrm{A}$, no filter $)$ and $30 \mathrm{kV}(2000 \mu \mathrm{A}$, Pd-thick filter). In the end, the measurements for each sediment core segment were compiled to one composite record with a total length of $940.5 \mathrm{~cm}$.

To determine the organic matter and the carbonate content, loss-on-ignition (LOI) on 108 samples was performed. $1 \mathrm{~cm}^{3}$ of sediment every $8 \mathrm{~cm}$ were taken and treated following Heiri et al. (2001).

\section{Pollen and charcoal analyses}

105 samples for pollen and microscopic charcoal analysis were retrieved from the sediment core from $11.40 \mathrm{~m}$ to the top. The standard sampling was $1 \mathrm{~cm}^{3}$ every $8 \mathrm{~cm}$. For the three lowest samples, $2 \mathrm{~cm}^{3}$ were taken due to low pollen concentrations. The samples were treated with $\mathrm{HCl}, \mathrm{KOH}, \mathrm{HF}$, acetolysis, 
sieved with a $0.5 \mathrm{~mm}$ sieve and mounted in glycerin following standard methods (Moore et al. 1991).

Lycopodium tablets were added before the chemical treatment for estimating microscopic charcoal, pollen and spore concentrations (Stockmarr 1971). Pollen and spores were identified using palynological keys (Moore et al. 1991; Beug 2004), photo atlases (Reille 1992) and the reference collection at the Institute of Plant Sciences at Bern University. Betula nana pollen was separated from tree Betula pollen following Birks (1968) and Clegg et al. (2005). A total number of 212 terrestrial pollen types were identified. A pollen sum of $>500$ terrestrial pollen grains per sample was counted. Pollen are presented in percentages calculated on the terrestrial pollen sum excluding Cannabis sativa pollen.

To test if the laminations are varves, five light brown and four dark brown layers between 333.6-332.5 cm were scraped off under a binocular following Welten (1944) and Lotter (1989) and treated separately with above mentioned standard methods. A pollen sum of $>400$ terrestrial pollen grains per sample was counted. These samples are presented in percentages of the terrestrial pollen sum according to their flowering season (Lauber et al. 2014). Microscopic charcoal particles $>10 \mu \mathrm{m}$ were analysed and counted following Tinner and $\mathrm{Hu}$ (2003) and Finsinger and Tinner (2005).

The main diagram (Fig. 3) was separated into six local pollen assemblage zones (LPAZ) identified by the use of optimal sum-of-squares partitioning (Birks and Gordon 1985) with the program ZONE 1.2 (Juggins 1991). The statistically significant zones were determined with the program BSTICK following the broken-stick method (Bennett 1996). For a better separation of the lowest part, LPAZ Burg-1 was split up into two sub-zones (Burg-1a and Burg-1b) that were not statistically significant.

\section{Results and interpretation}

\section{Seismic survey and bathymetry}

The seismic signal could not penetrate the sediments probably due to gas accumulation. The bathymetry shows two c. $30 \mathrm{~m}$ deep basins separated by an east-west oriented ridge (Fig. 1). The slopes of the lake basin are steep with some slightly shallower parts in the east. The corings in 2009 (Burg A-C) and in 2014 (Burg I) took place in the deepest part of the southern basin at a water depth of $31 \mathrm{~m}$. 


\section{Sedimentation and lithology}

The lowermost part of the sediment core $(1,500-1,037 \mathrm{~cm}, 18,700 \mathrm{cal}$ B.P. and older) consists of clay and sand layers. According to the age-depth model (Fig. 2), sedimentation rates are relatively constant between 18,700-4,000 cal B.P. From 1,037-846 cm (18,700-14,500 cal B.P.), the sediments consists of silt without sandy layers. Probably as a consequence of the smooth topography and the absence of major inflows and big streams from melting glaciers (Müller-Beck 2005a), stable soil conditions were established shortly after deglaciation. From $846 \mathrm{~cm}$ (14,500 cal B.P.) on, the sediment consists of fine detritus gyttja, partly laminated at $836-823 \mathrm{~cm}$ (around $13,900 \mathrm{cal}$ B.P.), at $812-739 \mathrm{~cm}(13,250-11,450$ cal B.P.) and from $604 \mathrm{~cm}(6,800 \mathrm{cal}$ B.P. $)$ to the top with only minor gaps. The uppermost $500 \mathrm{~cm}$ (from c. 4,000 cal B.P. on) are marked by an increase of sedimentation rates, most likely due to more erosional input in response to anthropogenic disturbance close to the lake shore (Figs. 3, 4).

Loss-on-ignition (LOI) inferred organic content is low $(<5 \%)$ for the bottom part of the sediment (Fig. 4) but steadily increases to values of just below $10 \%$ at $922-842 \mathrm{~cm}(15,950-14,200 \mathrm{cal}$ B.P.). This trend is interpreted as an increase of lake productivity and/or soil stabilization under warming environmental conditions. Organic content increases after $842 \mathrm{~cm}(14,200 \mathrm{cal}$ B.P.), when values reach up to $50 \%$. At $809-744 \mathrm{~cm}(13,150-11,550 \mathrm{cal}$ B.P.) the organic content drops again below $35 \%$. This falls into the second laminated sequence with increased XRF-inferred Fe, Ti and Mn elements (Fig. 4). Chronologically, this shift falls into the Younger Dryas cooling. Subsequently at the onset of the Holocene, the organic content is increasing again and stays at around $55 \%$ until c. $500 \mathrm{~cm}(4,050 \mathrm{cal}$ B.P.). Afterwards, organic values are continuously decreasing to below $15 \%$ in the uppermost sediments. This shift is probably due to more erosional input as a consequence of human activities (e.g. open soils). The third laminated part (6,800 cal B.P. - present) again shows increased Fe- and Mn values. The carbonate content of the sediment is generally low (LOI 950, XRF Ca), reaching c. 5\% on an average. Only in the bottom part and in the uppermost part, the values are slightly increased (10-20\%) possibly due to inwash of allochthonous carbonates.

\section{Varve identification}


The pollen percentages of the most abundant taxa in the seasonal layers (dark vs. bright) at 333.6-332.5

cm show that Corylus avellana and Alnus glutinosa-type pollen have higher relative values in the dark brown layers (Fig. 5). These two taxa are mainly flowering early on the Swiss Plateau from February to March (Lauber et al. 2014). On the other hand, herb pollen such as Poaceae, Cyperaceae, Cerealia-type, Secale, Plantago lanceolata and Rumex-type, generally flowering from April to September, have their highest values in the light brown layers. Some pollen types like Betula, Fagus sylvatica, Quercus and Abies alba show no clear signal due to their intermediate and overlapping flowering season from March to May. Thus, dark layers correspond to late autumn-early spring, while bright layers correspond to the summer season, confirming earlier studies from the Swiss Plateau and lowland Alps (Welten 1944, Lotter 1989).

The XRF data of the laminated sequence at $332.2-333.3 \mathrm{~cm}$ show that the laminated couplets consist of two main layers with a distinct elemental signature (Fig. 6). The dark brown layers are dominated by fine organic matter with low concentrations of $\mathrm{Mn}$ and $\mathrm{Ca}$, while the light brown layers are enriched in these elements. Rhodochrosite $\left(\mathrm{MnCO}_{3}\right)$ as an authigenic Mn-rich mineral is mainly found in these light brown layers (van Raden 2012). This is probably related to redox reactions occurring in the lake water and the pore water of the sediment (Stevens et al. 2000; Wetzel 2001). During the mixing of Mn enriched bottom waters and oxygen enriched surface waters, authigenic $\mathrm{Mn}$ is formed from Mn oxides. A stable Mn-rich layer is only preserved when anoxic conditions with no bioturbation are re-established and the reducing process is slower than the sedimentation process (Davison 1993; Stevens et al. 2000). Thus the XRF analyses confirm and refine the palynological results with dark layers formed during late autumn-early spring and the light layers during late spring-early autumn.

\section{Vegetation and fire history}

The pollen diagram (Fig. 3) is subdivided into six statistically significant local pollen assemblage zones (LPAZ) and two subzones Burg-1a und 1b. LPAZ Burg-1a (18,700-16,000 cal B.P.) is dominated by herbaceous pollen (values over $80 \%$ ) such as Poaceae, Cyperaceae, Artemisia, Helianthemum, Thalictrum, Chenopodiaceae, Rubiaceae and Rumex acetosa-type. These pollen results point to the establishment of open steppe/tundra vegetation shortly after deglaciation (c. 19,000 cal B.P., Beckmann 
2004). Some pollen grains of Betula nana, Ephedra distachya-type and Juniperus are present, indicating

that these shrubs were growing in the area. The presence of shrub vegetation is underlined by the finding of two woody twiglets that provided radiocarbon dates at the onset and towards the end of this subzone (Tab. 1). Charcoal influx values are very low, pointing to very low regional fire activity due to a sparse vegetation cover that mainly consisted of herbs.

The beginning of the next subzone (LPAZ Burg-1b: 16,000-14,300 cal B.P.) is marked by an increase of tree Betula pollen percentages to values of up to $15 \%$. This shift is accompanied by the highest Betula nana pollen percentages (up to $10 \%$ ) of the entire record. Additionally, other shrub pollen such as Ephedra distachya-type and Salix are found. Fruit scales and fruits of Betula nana used for radiocarbon dating (Tab. 1) and the increase of arboreal pollen point to a spread of shrub tundra with Betula nana and Salix around Burgäschisee. Tree Betula could have grown as small shrubs or krummholz as they do today at treeline in the Alps. The high non-arboreal values (> $60 \%$ with abundant Artemisia, Chenopodiaceae, Helianthemum), show that steppic environments were prevailing, pointing to the presence of steppe tundra. The highest percentage (up to $1 \%$ ) and influx values (up to 70 spores $/ \mathrm{cm}^{2} \mathrm{yr}$, not shown) of Sporormiella as well as the occurrence of Cercophora coprophilous fungal spores, point to large herbivores close to the lake shore (van Geel, 2006). These spores are normally interpreted as evidence for pastoral farming from the Neolithic on (e.g. Rey et al. 2014). Their marked presence in the Oldest Dryas steppe tundra can be explained to the presence of Pleistocene megafauna such as Mammuthus primigenius (woolly mammoth), Bison bonasus (bison) and Rangifer tarandus (reindeer), typical for the steppic environments at that time and fits well with the presence of Palaeolithic hunting camps at the former lake shore attributed to this period (Wyss 1952). A small charcoal peak at the beginning of the subzone around $16,000 \mathrm{cal} \mathrm{BP}$ suggests a minor increase of fire activity, possibly due to more fuel availability and/or warming climate.

Afforestation (LPAZ Burg-2, 14,300-13,500 cal B.P.) and the gradual replacement of the steppe tundra started with a short-term mass expansion of shrubs (Juniperus pollen percentages $>60 \%$, Salix and Hippophä̈ rhamnoides pollen percentage increase) during the Bølling warming period (onset c. 14,600 cal B.P., van Raden et al. 2013). This juniper shrubland phase lasted c. 200 years, and was followed by a sharp rise in tree Betula pollen, suggesting the formation of birch forests. The latter 
vegetational change marked the final collapse of the steppic tundra environments (decline of Betula nana, Artemisia, Chenopodiaceae). At the same time, around 14,300 cal B.P., the organic content of the sediment rises sharply, showing increased organic productivity in the lake. Herb, shrub and tree pollen concentrations remain more or less constant (Fig. 4), suggesting stable sedimentary conditions. Regional fires were still very rare as shown by low charcoal influx values.

Pollen results suggest that mixed birch and pine forests established around 13,500 cal B.P. (LPAZ Burg-3, 13,500-10,800 cal B.P.). This vegetation type persisted through the Allerød period (13,900-12,900 cal B.P., van Raden et al. 2013) as indicated by the pollen assemblages. Quercus pollen is regularly found, possibly as a result from long distance transport from the adjacent region south of the Alps, where oak stands grew at that time (Monegato et al. 2007; Finsinger et al. 2006). Given that the empirical limit (closed curve, Birks and Tinner 2016) is almost reached, these stands could, however, have been located closer to the site, perhaps in the nearby Rhone valley (c. $90 \mathrm{~km}$ distance), which opens to the Mediterranean Sea. Around 12,800 cal B.P., Pinus sylvestris-type pollen becomes dominant, followed by a marked increase of herb pollen (c. $25 \%$, e.g. Poaceae, Artemisia), a minor increase of Juniperus pollen (c. $5 \%$ ) and a decrease of Betula pollen (below $20 \%$ ) in the upper part of the zone (c. 12,600-11,200 cal B.P.). We interpret this opening of the forests as a result of climate cooling during the Younger Dryas (12,710-11,500 cal B.P.; Vescovi et al. 2007; van Raden et al. 2013). Shortly after the onset of the Holocene, after c. 11,500 cal B.P., closed mixed birch-pine forest re-established as indicated by high arboreal pollen percentages (from 80 to $95 \%$ ). Continuous curves of Quercus, Ulmus, Tilia and Alnus glutinosa-type pollen suggest the establishment of temperate forest stands in response to rapid climate warming at the onset of the Holocene (Heiri et al. 2015). Charcoal influx values increase temporarily (c. 1,200 particles/ $\mathrm{cm}^{2} \mathrm{yr}$ ) at the onset of the Allerød and at the onset of the Holocene, suggesting increased burning during these transition periods.

Pollen of temperate trees and shrubs such as Ulmus, Quercus, Tilia, Acer, Corylus avellana and Hedera helix increases during LPAZ Burg-4 (10,800-7,500 cal B.P.), suggesting a further expansion of temperate deciduous forests at the expenses of boreal forests (tree Betula and Pinus sylvestis-type pollen declines). After c. 9,000 cal B.P., Fraxinus excelsior pollen percentages and Alnus glutinosa-type percentages increase and Abies alba and Fagus sylvatica reached their empirical limit (at 8,100 cal B.P. 
and 7,700 cal B.P. respectively), suggesting that these trees expanded locally (Birks and Tinner, 2016).

At the same time, Corylus avellana pollen percentages start to decrease, indicating that heliophilous hazel shrublands were gradually reduced by more mesophilous vegetation. Regional fire activity was moderate during the first half of the zone $(10,800-9,000$ cal B.P.) as indicated by intermediate charcoal influx values. After c. 9,000 cal B.P., charcoal influx values decrease, suggesting less burning. This decline of regional fires and the spread of mesophilous trees can be attributed to a decline in summer insolation (Wanner et al. 2008) and a shift towards a more oceanic climate reflected by higher lake levels (Magny 2011).

Pollen data suggest that during LPAZ Burg-5 (7,500-900 cal B.P.), Fagus sylvatica became the dominant tree species together with Abies alba, forming dark mesophilous beech-fir forests that gradually replaced the previously prevailing mixed elm-linden-maple-oak forests. At c. 6,500 cal B.P. (4,550 cal B.C.), the first pollen grains of Cerealia-type and Plantago lanceolata appear in the pollen sequence, marking the onset of conspicuous agricultural activities around Burgäschisee. Occurrence of Linum usitatissimum-type pollen, Allium-type pollen, Hypericum perforatum-type pollen, Cerealia-type pollen, Plantago lanceolata pollen suggest Neolithic arable and pastoral farming close to the lake at around 5,750 cal B.P (3,800 cal B.C., Cortaillod Culture). Towards the upper part of the zone, herbaceous pollen becomes more frequent indicating that open land increased. Betula trees, a typical successional pioneer tree, spread again. Tilia pollen disappears (temporarily) during this LPAZ, suggesting that Tilia trees became locally very rare or even extinct during the Bronze Age c. 3,500 cal. B.P. (1,550 cal B.C.) (Tinner et al. 2005). Remarkable transient closings of forests (AP > $95 \%$ ) occurred during the Bronze Age and during the Late Roman to Early Medieval period. Charcoal influx show moderate to high values, suggesting higher regional fire activity that peaked around $6,500-5,000 \mathrm{cal}$ B.P. (4,550-3,050 cal B.C.) and 3,000-2,000 cal B.P. (1,050-50 cal B.C.), most likely in response to human activities such as slash-and-burn.

Land-use intensified during the Middle Ages and later, as shown by herb pollen percentages of up to $40 \%$ (LPAZ Burg-6, 900 cal B.P.-present). Typical for this time is the spread of Cannabis sativa, an important fibre plant, reaching maximum values around $800 \mathrm{cal}$ B.P. (1,150 cal A.D.). The high pollen percentage values of Cannabis sativa is due to retting of the entire plant in the lake (Ranalli and 
Venturi 2004) and is therefore a good biostratigraphic marker (Gobet and Tinner 2012). Charcoal influx

values show two major peaks. At the same time, herb pollen percentages are highest, indicating massive regional forest burnings to expand agricultural land.

\section{Discussion}

\section{Deglaciation and vegetation dynamics during the Oldest Dryas north and south of the Alps}

The glacier extent during the Last Glacial Maximum (LGM) has been intensively investigated by analyzing the distribution and age of moraines and glacial landforms (Jäckli, 1962, Bini et al. 2009). Recently, the dating of moraines with the ${ }^{10} \mathrm{Be}$ method has become established in the Alps and their forelands (e.g. Federici et al. 2012; Ivy-Ochs et al. 2004; Reber et al. 2014; Gianotti et al. 2008; Reuther et al. 2011). All these studies suggest an age for the LGM ranging from $24,000-18,000$ cal B.P., which is in agreement with palaeoecological and palaeoclimatic records from radiocarbon-dated sites close to the Alps that had never been glaciated (e.g. Kaltenrieder et al. 2009; Samartin et al. 2016, LGM c. 23,000-19,000 cal B.P.). However, the error of the ${ }^{10} \mathrm{Be}$ surface exposure dating is substantial (usually $\pm 1,000-2,000$ years) and thus the assessment of local deglaciation dynamics is only preliminary. Here, independent radiocarbon dating of terrestrial macrofossils deposited in lake sediments from sites located within the margin of the former ice sheet might help to date the spatial deglaciation patterns more precisely. Earliest dates on terrestrial plant remains for lowland sites in the Alpine region that were icecovered during the LGM are available from south and north of the Alps (Tab. 2). Burgäschisee, Wauwilermoos (Beckmann 2004) and Lago Piccolo di Avigliana (Larocque and Finsinger 2008) are all located at the margins of the LGM ice cover (Ehlers and Gibbard 2004; Bini et al. 2009) and have radiocarbon dates that are all older than 18,000 cal years. The radiocarbon dates from Rotsee (Lotter and Zbinden 1989), Soppensee (Lotter et al. 1997; Lotter 1999) and Lago di Origlio (Tinner et al. 1999) are slightly younger (around 17,500 cal B.P.). These lakes were located below rather thick ice sheets (800-1,000 m) and 15-20 km away from the glacier front. The rather small age difference between these lakes suggests that the deglaciation process in the lowlands was fast (within $<1,000$ years). This sudden retreat of the glaciers and the reduction of ice mass may have been triggered by increasing 
summer insolation (Berger and Loutre 1991) and increasing $\mathrm{CO}_{2}$ concentrations (Smith et al. 1999). Similar patterns are evident from ${ }^{10} \mathrm{Be}$ exposure dated boulders and bedrock on nunataks in the Inner Alps (Wirsig et al. 2016).

The change in the lithology (Figs. 3,4) suggests that pioneer plants colonized the glacier forelands at Burgäschisee and the pollen evidence shows that a species rich steppe tundra established, stabilizing the soils rapidly after deglaciation at 19,000 cal B.P. Arboreal plants, dwarf shrubs and shrubs, formed thickets (e.g. dated macrofossils of Ericaceae and other shrubs; Beckmann 2004; this study). Other sites in the Swiss Plateau lowlands such as Murifeld (Welten 1982), Faulenseemoos (Welten 1944, 1982), Lobsigensee (Ammann and Tobolski 1983; Ammann 1989), Rotsee (Lotter and Zbinden 1989), Le Loclat (Hadorn 1992), Soppensee (Lotter 1999) and Wauwilermoos (Beckmann 2004) show similar pioneer vegetation patterns in the deepest parts of the analysed section. However, only Rotsee, Soppensee and Wauwilermoos have radiocarbon dates for this early phase prior to 16,000 cal B.P. South of the Alps, Juniperus stands expanded as early as 18,000-17,500 cal. B.P. in the formerly glaciated areas of the Ticino area (e.g. Origlio, Tinner et al. 1999; Vescovi et al. 2007). Stomata and macrofossils findings at e.g. Lago di Ragogna (Monegato et al. 2007) in eastern Italy, at Lago Piccolo di Avigliana (Finsinger et al. 2006) in western Northern Italy suggest that Larix decidua, tree Betula and Pinus sp. occurred between 17,500-16,000 cal B.P., after having expanded from their unglaciated refugial sites (e.g. Euganean Hills in the Eastern Po-Plain, Kaltenrieder et al. 2009). It is likely that these early post-LGM vegetation dynamics resulted from climate warming of around $3{ }^{\circ} \mathrm{C}$ after c. 19,000 cal B.P. (Samartin et al. 2016).

Vegetation changed around 16,000 cal. B.P. at Burgäschisee with an expansion of shrub tundra (pollen of tree Betula, Betula nana, Salix, Juniperus). First macrofossils of Betula nana show that dwarf birch thickets were wide-spread in the landscape. This vegetational re-organization is well documented at many lowland sites north of the Alps (e.g. Welten 1982; Lotter 1999). We assume that Betula humilis (shrubby birch) and Betula trees (e.g. Betula pubescens) were growing in the most favorable habitats, however, their local presence has not been confirmed by radiocarbon-dated macrofossil finds so far. At around 16,700-16,000 cal B.P., forests expanded (e.g. Pinus cembra, Larix decidua) at lowland sites south of the Alps (e.g. Wick 1996; Tinner et al. 1999; Hofstetter et al. 2006; Vescovi et al. 2007; Pini et 
al. 2016), far before the onset of the Bølling period and sites above $1,000 \mathrm{~m}$ a.s.l. became ice-free (e.g. Palughetto at 1,040 m a.s.l. (Vescovi et al. 2007), Pian di Gembro at 1,350 $\mathrm{m}$ a.s.l. (Pini 2002)). These major vegetation and environmental changes are likely the response to Late-Glacial warming of c. 2.5 ${ }^{\circ} \mathrm{C}$ higher summer temperatures after Heinrich event 1 (Samartin et al. 2012).

The high abundance of coprophilous spores (Sporormiella, Cercophora) at Burgäschisee during the Late Glacial period from 17,000-14,300 cal B.P during the steppe tundra vegetation phase is striking. In North America, coprophilous fungal spores in the Late Glacial were connected to the presence of the last Pleistocene large herbivores such as Mammuthus primigenius (woolly mammoth), Bison bison (American bison) and Rangifer tarandus (reindeer) (Robinson et al. 2005; Davis and Shafer 2006; Gill et al. 2012). In Siberia, an excavation revealed high numbers of Sporormiella spores next to a mammoth carcass (Mol et al. 2006). Findings of mammoth, reindeer and bison remains are abundant in Switzerland until c. 14,000 cal B.P. (Fahlke 2009, Nielsen 2013). Numerous flints were found at the hunting camps of Fürsteiner (Wyss 1952) that existed at the same time as the Pleistocene herbivores on the former Burgäschisee lake shore and were assigned to the Magdalenian $(18,000-14,000$ cal B.P. $(16,050-12,050$ cal B.C.), Le Tensorer 1993; von Burg et al. 2011).

\section{Vegetation and fire dynamics on the Alpine Foreland during the last 14,500 years}

The mass expansion of Juniperus followed by the establishment of Betula woodlands occurred at c. 14,300 cal B.P. This is c. 200-250 later than at Gerzensee (van Raden et al. 2013) and the difference is probably due to calibration uncertainties attributed to the radiocarbon plateau at the onset of the Bølling (Reimer et al. 2013). This initial afforestation is well documented in many lowland records north of the Alps (e.g. Lotter 1999; Beckmann 2004; Ammann and Tobolski 1983) including a pioneer land core from Burgäschisee (Welten 1946). Montane to subalpine sites in the Alps became ice-free up to $1800 \mathrm{~m}$ a.s.l. (Welten 1982; Ilyashuk et al. 2009; Rey et al. 2013) and dense boreal forests (e.g. Pinus sylvestris, tree Betula) established south of the Alps (Tinner et al. 1999; Hofstetter et al. 2006). South of the Alps forests expanded from elevations of about $800 \mathrm{~m}$ to at least 1,350 m a.s.l. (Pini 2002; Vescovi et al. 2007), showing that the Bølling warming released an upslope movement of about 500-600 m. Forest expansions in Southern and Central Europe followed a rapid $3-4{ }^{\circ} \mathrm{C}$ warming, as e.g. recorded in stable 
isotopes and chironomid records (Heiri and Millet 2005; Heiri et al. 2007; Larocque and Finsinger 2008;

Larocque-Tobler et al. 2010; Lotter et al. 2012).

Subsequently fairly dense mixed Pinus sylvestris and Betula forests formed during the Allerød period (c. 13,500 cal. B.P.) at Burgäschisee. This spread of boreal forests occurred across the entire Swiss Plateau (e.g. Lotter 1999; Wick 2000) and elsewhere in Central Europe (e.g. Becker et al. 2006; Kleinmann et al. 2015). Closed forests in combination with stable and warm summer temperatures (Heiri et al. 2015) possibly led to an increase of regional fires. South of the Alps temperate trees (e.g. Tilia, Quercus, Ulmus, Fraxinus excelsior) invaded the Allerød boreal forests (Tinner et al. 1999; Vescovi et al. 2007), as also unambiguously documented by macrofossils (Finsinger et al. 2008; Monegato et al. 2007).

During the Younger Dryas cooling (c. 12,710-11,500 cal B.P.), steppe-tundra vegetation including Artemisia, Chenopodiaceae, Poaceae and others temporarily recovered. Forest disruption with a decline of short-lived tree Betula and the dominance of long-lived Pinus sylvestris is typical for Central Europe and is confirmed by macrofossil analysis (Lotter 1999). South of the Alps forest disruption was less marked, however, temperate trees such as Quercus markedly declined (Finsinger et al. 2006). After 11,400 cal B.P., at the onset of the Holocene, mixed Pinus sylvestris and Betula forests recovered quickly in both regions. Chironomid-based summer temperature reconstructions suggest a rapid warming of c. $3{ }^{\circ} \mathrm{C}$ at the onset of the Holocene (e.g. Heiri et al. 2015). However, forest composition changed significantly after 10,800 cal B.P. when boreal forests were gradually replaced by temperate forests consisting of Tilia, Ulmus, Acer, Hedera helix and Corylus avellana. These species characterized the forests over 4,000 years in Central Europe (e.g. Clark et al. 1989; Hadorn 1992; Richoz 1998; Lotter 1999; Litt et al. 2009) and reflect natural forest composition under warm but rather continental conditions (maximum summer and minimum winter solar insolation; Kutzbach and Webb 1993).

These continental forests around Burgäschisee remained stable until c. 8,500-8,000 cal B.P. when Alnus and Fraxinus increased and Abies alba as well as Fagus sylvatica established. Alnus and Fraxinus are still growing at the lake shore today. Both trees can cope with wet soil conditions and generally grow in moist forests (Lauber et al. 2014). Fagus sylvatica and Abies alba are both shadetolerant mesophilous late-successional trees species. The shift to mixed beech forests was found at many 
sites on the Swiss Plateau (e.g. Ammann 1989; Lotter 1999) and the reasons for this change have been can be substantial. For instance, on the Western Swiss Plateau close to the Jura Mountains Fagus sylvatica was co-dominant with Quercus (Ammann 1989; Hadorn 1992; Richoz 1998). Abies alba was less abundant possibly due to drier conditions in the shade of the Jura Mountains. At Burgäschisee, Abies alba was locally present (Tab. 1) but its abundance was moderate and corresponds to that at other sites in Western Switzerland. Higher Abies alba abundances (values $>15 \%$ ) occurred in the lowland areas of Central and Eastern Switzerland, e.g. at Wauwilermoos, Bibersee and Zürichsee (Beckmann 2004; Gobet et al. 2016). A general trend to increasing Abies alba abundances is also evident with increasing altitude (Lotter 1999; van der Knaap et al. 2004; Wehrli et al. 2007; Gobet and Tinner 2012), probably also reflecting a moisture gradient, given that the species is more competitive under mesophilous conditions, particularly if exposed to excessive anthropogenic disturbance (e.g. fire, browsing, Tinner et al. 1999, 2013; Henne et al. 2013; Ruosch et al. 2016).

The onset of noticeable agricultural activities around Burgäschisee dates to c. 6,500 cal B.P. $(4,550$ cal B.C.) in our pollen record. This inference is in good agreement with the archaeological evidence, with single Neolithic archaeological finds dated to the period after $6,250 \mathrm{cal}$ B.P. $(4,300 \mathrm{cal}$ B.C.) and by the existence of local settlements after c. 5,950 cal B.P. (4,000 cal B.C., Wey 2012). The expansion of arable and pastoral farming (e.g. Cerealia-type, Plantago lanceolata, Linum usitatissimumtype) as well as of disturbance-adapted Fagus sylvatica, Corylus avellana and Betula is typical for the lowland in Central Europe. It may generate successional cycles that might be recognized depending on the temporal resolution of the records (e.g. Kleinmann et al. 2015; Rösch and Lechterbeck 2016). Forest disruptions and land use phases were associated with increasing fire activity (Clark et al. 1989; Tinner et al. 2005), suggesting that fire was intensely used to gain open land and contributed to the reduction of fire sensitive trees and lianas (e.g. Tilia, Ulmus, Fraxinus, Acer, Abies alba, Hedera helix). Interestingly, at Burgäschisee this first Neolithic forest disruption coincided with the onset of the formation of varves in the sediment. This may indicate changes in the mixing system of Burgäschisee, probably due to a more open landscape because of forest clearance and therefore increased windiness as a trigger for short-term mixing (Davison 1993; Stevens et al. 2000; van Raden 2012). 
Land use intensified during the Mid Bronze Age (around 3,500 cal B.P., 1,550 cal B.C.) and the Iron Age (after 2,800 cal B.P., 850 cal B.C.) when fire-sensitive trees such as Tilia (Tinner et al. 2005) collapsed completely. Most of the Neolithic log boats were built out of Tilia trunks (Hafner et al. 2012) whereas the Bronze Age log boats were mainly made of harder oak trunks (Mainberger 2009) that are more difficult to work on. This depletion of the preferentially used linden trees can be considered a prehistoric example of inadequate handling of natural resources. Similar intensifications of land-use during the Bronze and Iron Age have been reconstructed at Lobsigensee (Ammann 1989) and at Le Loclat (Hadorn 1992) documenting the importance of the Swiss Plateau lowlands (< $600 \mathrm{~m}$ a.s.l.) for crop production. In contrast to that, more remote study sites e.g. Soppensee (Lotter 1999), Schwantenau (Gobet and Tinner 2012), Egelsee (Wehrli et al. 2007) only experience strong openings of the forests during the Middle Ages (c. 800 cal B.P., 1,150 cal A.D.), when less fertile areas (colder, moister) became also intensively used.

\section{Conclusions}

We reconstruct vegetation, fire and land use dynamics over the past 18,700 years at a novel site. We can demonstrate the sediments of Burgäschisee are varved over millennia. A radiocarbon age of a twiglet provided a calibrated age of c. 18,700 cal B.P, which is one of the earliest absolute date for the establishment of vegetation after the LGM on the Swiss Plateau. Late Glacial vegetation dynamics at c. $19,000-18,000,16,000,14,500,11,600$, and 8,200 cal years ago were closely connected to climate changes, in particular warming and/or increase of moisture availability. Frequently found coprophilous spores (Sporormiella, Cercophora) suggest the presence of Pleistocene large herbivores (e.g. Mammuthus primigenius) during the non-forested Late Glacial, c. 17,000-14,000 cal B.P. After the onset of the Neolithic c. 7500 years ago vegetation changes were primarily controlled by human activities, including fire disturbance. These societally induced changes, specifically deforestation, likely released the formation of varved sediments that are unique for the Swiss Plateau. As varved sediments allow a precise chronology comparable to that of tree rings, the Burgäschisee record has a great potential for further multi-proxy high resolution studies. Such investigations would offer the possibility of 
reconstructing short-term vegetation changes, responses to climate shifts and/or anthropogenic disturbance. Specifically, the ecological and environmental consequences of short-lived Neolithic lake shore settlements (lasting less than 30 years, Bleicher and Burger 2015) might be investigated and linked to the tree ring records from prehistoric villages. Complex linkages between climate, vegetation, fire and land use might be explored with sufficient time resolution and precision, an endeavour which has not been achieved so far for the Swiss Plateau and adjacent areas of Central Europe. 


\section{References}

Ambühl H, Stumm W (1984) Bericht über die Auswirkungen der Tiefenwasserableitung im Burgäschisee. EAWAG

Ammann B, Tobolski K (1983) Vegetational development during the Late-Würm at Lobsigensee (Swiss Plateau). Studies in the late Quaternary of Lobsigensee 1. Rev Paléobiol 2(2):163-180

Ammann B (1989) Late-Quaternary palynology at Lobsigensee. Regional vegetation history and local lake development. Diss Bot 137:1-157

Ammann B, Lotter AF (1989) Late-Glacial radiocarbon- and palynostratigraphy on the Swiss Plateau. Boreas 18:109-126

Ammann B, Eicher U, Gaillard M-J, Haeberli W, Lister G, Lotter AF, Maisch M, Niessen F, Schlüchter C, Wohlfarth B (1994) The Würmian Late-glacial in lowland Switzerland. J Quat Sci 9(2):119-125

Ammann B, Gaillard M-J, Lotter AF (1996) Switzerland. In: Berglund BE, Birks HJB, RalskaJasiewiczowa M, Wright HE (eds) Palaeoecological events during the last 15000 years: regional syntheses of palaeoecological studies of lakes and mires in Europe. Wiley, Chichester, pp 647-666

Arn H (1945) Die Melioration des Gebietes um den Burgäschisee und die Seeabsenkung. Tierwelt $11: 1-12$

Becker A, Ammann B, Anselmetti FS, Hirt AM, Magny M, Rachoud A-M, Sampietro G, Wühtrich C (2006) Paleoenvironmental studies on Lake Bergsee, Black Forest, Germany. Neu Jahrb Geol Paläont Abh 240(3):405-445

Beckmann M (2004) Pollenanalytische Untersuchung der Zeit der Jäger und Sammler und der ersten Bauern an zwei Lokalitäten des Zentralen Schweizer Mittellandes. Diss Bot 390:1-223

Bennett KD (1996) Determination of the number of zones in a biostratigraphical sequence. New Phytol 132(1):155-170

Berger A, Loutre M-F (1991) Insolation values for the climate of the last 10,000,000 years. Quat Sci Rev 10(4):297-317

Beug H (2004) Leitfaden der Pollenbestimmung für Mitteleuropa und angrenzende Gebiete. Pfeil, München

Bini (2009) Die Schweiz während des letzteiszeitlichen Maximums (LGM) 1:500,000, Bundesamt für Landestopographie swisstopo

Birks HJB (1968) The identification of Betula nana pollen. New Phytol 67(2):309-314

Birks HJB, Gordon AD (1985) Numerical methods in quaternary pollen analysis. Academic Press, London, Orlando

Birks HJB, Heegaard E (2003) Developments in age-depth modelling of Holocene stratigraphical sequences. PAGES News 11:7-8

Birks HJB, Tinner W (2016). European tree dynamics and invasions during the Quaternary. In: Krumm F, Vítková L (eds) Introduced tree species in European forests: opportunities and challenges. European Forest Institute, Freiburg, pp 22-43

Blaauw M (2010) Methods and code for 'classical' age-modelling of radiocarbon sequences. Quat Geochronol 5(5):512-518 
Bleicher N, Burger M (2015) Dendroarchäologie und Pfahlfeldanalyse. In: Bleicher N, Harb C (eds) Zürich-Parkhaus Opéra - Eine neolithische Feuchtbodenfundstelle. Band 1: Befunde, Schichten und Dendroarchäologie. Monographien der Kantonsarchäologie Zürich 48, pp 100-146

Clark JS, Merkt J, Müller H (1989) Post-glacial fire, vegetation and human history on the northern alpine forelands, South-Western Germany. J Ecol 77(4):897-925

Clegg BF, Tinner W, Gavin DG, Hu FS (2005) Morphological differentiation of Betula (birch) pollen in northwest North America and its palaeoecological application. Holocene 16(2):791-803

Davis OK, Shafer DS (2006) Sporormiella fungal spores, a palynological means of detecting herbivore density. Palaeogeogr, Palaeoclimatol, Palaeoecol 237(1):40-50

Davison W (1993) Iron and manganese in lakes. Earth Sci Rev 34(2):119-163

Ehlers J, Gibbard PL (2004) Quaternary glaciations - extent and chronology: Part I: Europe. Elsevier, Amsterdam

Eicher (1987) Die spätglazialen sowie die frühpostglazialen Klimaverhältnisseim Bereiche der Alpen: Sauerstoffisotopenkurven kalkhaltiger Sedimente. Geogr Helv 2:99-104

Fahlke (2009) Der Austausch der terrestrischen Säugetierfauna an der Pleistozän/Holozän-Grenze in Mitteleuropa. Dissertation, Universität Bonn

Federici PR, Granger DE, Ribolini A, Spagnolo M, Pappalardo M, Cyr AJ (2012) Last glacial maximum and the Gschnitz stadial in the Maritime Alps according to ${ }^{10} \mathrm{Be}$ cosmogenic dating. Boreas 41(2):277-291

Finsinger W, Tinner W (2005) Minimum count sums for charcoal concentration estimates in pollen slides: accuracy and potential errors. Holocene 15(2):293-297

Finsinger W, Tinner W, van der Knaap WO, Ammann B (2006) The expansion of hazel (Corylus avellana L.) in the southern Alps: a key for understanding its early Holocene history in Europe? Quat Sci Rev 25(5-6):612-631

Geyh MA, Merkt J, Müller H (1971) Sediment-, Pollen-, und Isotopenanalysen an jahreszeitlich geschichteten Ablagerungen im zentralen Teil des Schleinsees. Arch Hydrobiol 69(3):366-399

Gianotti F, Forno MG, Ivy-Ochs S, Kubik PW (2008) New chronological and stratigraphical data on the Ivrea amphitheatre (Piedmont, NW Italy). Quat Int 190(1):123-135

Gill JL, Williams JW, Jackson ST, Donnelly JP, Schellinger GC (2012) Climatic and megaherbivory controls on late-glacial vegetation dynamics: a new, high-resolution, multi-proxy record from Silver Lake, Ohio. Quat Sci Rev 34:66-80

Gobet E, Tinner W (2012) Von der Ur- zur Kulturlandschaft. In: Meyerhans A (ed) Geschichte des Kantons Schwyz, Band 1: Zeiten und Räume, Frühzeit bis 1350. Historischer Verein des Kantons Schwyz. Chronos, Zürich, pp 37-57

Gobet E, van Leeuwen JFN, Tinner W (2016) Vegetationsdynamik, Landnutzung und Siedlungstätigkeit im Einzugsgebiet der Seeufersiedlungen im Unteren Zürichseebecken. In: Bleicher N, Harb C (eds) Zürich-Parkhaus Opéra - Eine neolithische Feuchtbodenfundstelle. Band 3: Naturwissenschaftliche Analysen und Synthese. Monographien der Kantonsarchäologie Zürich, pp 11-30

Guthruf J, Zeh M, Guthruf-Seiler K (1999) Kleinseen im Kanton Bern. Haupt, Bern, pp 32-34

Haas JN, Hadorn P (1998) Die Vegetations- und Kulturlandschaftsgeschichte des Seebachtals von der Mittelsteinzeit bis zum Frühmittelalter anhand von Pollenanalysen. In: Hasenfratz A, Schnyder M (eds) Das Seebachtal - Eine archäologische und paläoökologische Bestandesaufnahme. Forschungen im 
Seebachtal 1, Archäologie im Thurgau, vol. 4. Frauenfeld: Amt für Archäologie des Kantons Thurgau, pp 221-255

Hadorn P (1992) Vegetationsgeschichtliche Studie am Nordufer des Lac de Neuchâtel: Pollenanalytische Untersuchungen im Loclat, in der Bucht von Hauterive/Saint-Blaise und in den neolithischen Ufersiedlungen von Saint-Blaise/Bain des Dames. Dissertation, Universität Bern

Hafner A, Suter PJ (2003) Das Neolithikum in der Schweiz. J Neolith Archaeol, 5

Hafner A, Harb C, Amstutz M, Francuz J, Moll-Dau F (2012) Moosseedorf, Moossee Oststation, Strandbad - Strandbadneubau, Pfahlbauten und das älteste Boot der Schweiz. Jahrbuch des Archäologischen Dienstes des Kantons Bern, pp 71-77

Heegaard E, Birks HJB, Telford RJ (2005) Relationships between calibrated ages and depth in stratigraphical sequences: an estimation procedure by mixed-effect regression. Holocene 15(4):612-618

Heiri O, Lotter AF, Lemcke G (2001) Loss on ignition as a method for estimating organic and carbonate content in sediments: reproducibility and comparability of results. J Paleolimnol 25(1):101-110

Heiri O, Millet L (2005) Reconstruction of late glacial summer temperatures from chironomid assemblages in Lac Lautrey (Jura, France). J Quat Sci 20(1):33-44

Heiri O, Filippi ML, Lotter AF (2007) Lateglacial summer temperatures in the Trentino area (Northern Italy) as reconstructed by fossil chironomid assemblages in Lago di Lavarone (1100m a.s.1.). Studi Trent Sci Nat, Acta Geol 82:299-308

Heiri O, Ilyashuk B, Millet L, Samartin S, Lotter AF (2015) Stacking of discontinuous regional palaeoclimate records: Chironomid-based summer temperatures from the Alpine region. Holocene 25(1):137-149

Henne PD, Elkin C, Colombaroli D, Samartin S, Bugmann H, Heiri O, Tinner W (2013) Impacts of changing climate and land use on vegetation dynamics in a Mediterranean ecosystem: insights from paleoecology and dynamic modeling. Landscape Ecol 28:819-833

Hodel C, Bachmann A (2011) Bronzezeit. In: Hodel C, von Burg A, Marti R, Bachmann A (eds) Archäologie des Oberaargaus - Ur- und Frühgeschichte 13,000 v. Chr. bis 700 n. Chr. Sonderband 6. Jahrbuch des Oberaargaus, pp 53-67

Hofstetter S, Tinner W, Valsecchi V, Carraro G, Conedera M (2006) Lateglacial and Holocene vegetation history in the Insubrian Southern Alps - new indications from a small-scale site. Veget Hist Archaeobot 15(2):87-98

Ilyashuk BP, Gobet E, Heiri O, Lotter AF, van Leeuwen JFN, van der Knaap WO, Ilyashuk EA, Oberli F, Ammann B (2009) Lateglacial environmental and climatic changes at the Maloja Pass, Central Swiss Alps, as recorded by chironomids and pollen. Quat Sci Rev 28(13-14):1340-1353

Ivy-Ochs S, Schaefer J, Kubik PW, Synal HA, Schlüchter C (2004) Timing of deglaciation on the northern Alpine foreland (Switzerland). Eclogae Geol Helvetiae 97(1):47-55

Jäckli H (1962) Die Vergletscherung der Schweiz im Würmmaximum. Eclogae Geol Helvetiae 55:285-294

Juggins S (1991) Zone 1.2. Freeware. DOS Program for the Zonation (Constrained Clustering) of Palaeoecological Data. Available at: https://www.staff.ncl.ac.uk/stephen.juggins/software.htm (accessed 28.02.17)

Kaltenrieder P, Belis CA, Hofstetter S, Ammann B, Ravazzi C, Tinner W (2009) Environmental and climatic conditions at a potential Glacial refugial site of tree species near the Southern Alpine glaciers. 
New insights from multiproxy sedimentary studies at Lago della Costa (Euganean Hills, Northeastern Italy). Quat Sci Rev 28(25-26):2647-2662

Kleinmann A, Merkt J, Müller H (2015) Sedimente des Degersees: Ein Umweltarchiv - Sedimentologie und Palynologie. In: Mainberger M, Merkt J, Kleinmann A (eds) Pfahlbausiedlungen am Degersee, Archäologische und naturwissenschaftliche Untersuchungen. Landesamt für Denkmalpflege im Regierungspräsidium Stuttgart. Theiss, Darmstadt, pp 409-471

Kutzbach JE, Webb III T (1993) Conceptual basis for understanding Late-Quaternary climates. In: Wright Jr HE, Kutzbach JE, Webb III T, Ruddiman WF, Street-Perrott FA, Bartlein PJ (eds), Global Climates since the Last Glacial Maximum. University of Minnesota Press, Minneapolis, pp 5-11

Larocque I, Finsinger W (2008) Late-glacial chironomid-based temperature reconstructions for Lago Piccolo di Avigliana in the southwestern Alps (Italy). Palaeogeogr, Palaeoclimatol, Palaeoecol 257(1-2):207-223

Larocque-Tobler I, Heiri O, Wehrli M (2010) Lateglacial and Holocene temperature changes at Egelsee, Switzerland, reconstructed using subfossil chironomids. J Paleolimnol 43(4):649-666

Lauber K, Wagner G, Gygax A (2014) Flora Helvetica, 5th edn. Haupt, Bern

Le Tensorer J-M, Niffeler U (1993) SPM I, Paläolithikum und Mesolithikum. Verlag Schweizerische Gesellschaft für Ur- und Frühgeschichte, Basel

Litt T, Schölzel C, Kühl N, Brauer A (2009) Vegetation and climate history in the Westeifel Volcanic Field (Germany) during the past 11000 years based on annually laminated lacustrine maar sediments. Boreas 38(4):679-690

Lotter AF (1989) Evidence of annual layering in Holocene sediments of Soppensee, Switzerland. Aquat Sci 51(1):19-30

Lotter AF, Zbinden H (1989) Late-Glacial pollen analysis, oxygen-isotope record, and radiocarbon stratigraphy from Rotsee (Lucerne), Central Swiss Plateau. Eclogae Geol Helvetiae 82(1):191-202

Lotter AF, Merkt J, Sturm M (1997) Differential sedimentation versus coring artifacts: a comparison of two widely used piston-coring methods. J Paleolimnol 18(1):75-85

Lotter AF (1999) Late-glacial and Holocene vegetation history and dynamics as evidenced by pollen and plant macrofossil analyses in annually laminated sediments from Soppensee (Central Switzerland). Veget Hist Archaeobot 8(3):165-184

Lotter AF, Heiri O, Brooks S, van Leeuwen JFN, Eicher U, Ammann B (2012) Rapid summer temperature changes during Termination 1a: high-resolution multi-proxy climate reconstructions from Gerzensee (Switzerland). Quat Sci Rev 36:103-113

Magny M, Bossuet G, Ruffaldi P, Leroux A, Mouthon J (2011) Orbital imprint on Holocene palaeohydrological variations in west-central Europe as reflected by lake-level changes at Cerin (Jura Mountains, eastern France). J Quat Sci 26(2):171-177

Mainberger M (2009) An Early Bronze Age logboat from Degersee, Southern Germany. Int J Naut Archaeol 38(1)3-12

Marti R (2011) Frühmittelalter. In: Hodel C, von Burg A, Marti R, Bachmann A (eds) Archäologie des Oberaargaus - Ur- und Frühgeschichte 13,000 v. Chr. bis 700 n. Chr. Sonderband 6. Jahrbuch des Oberaargaus, pp 143-160 
Mol D, Tikhonov A, van der Plicht J, Kahlke R, Debruyne R, van Geel B, van Reenen G, Pals JP, de Peninsula, Arctic Siberia, Russian Federation. Quat Int 142-143:186-202

Monchamp M-E, Walser J-C, Pomati F, Spaak P (2016) Sedimentary DNA reveals cyanobacterial community diversity over 200 years in two perialpine lakes. Appl Environ Microbiol 82(21):6472-6482

Monegato G, Ravazzi C, Donegana M, Pini R, Calderoni G, Wick L (2007) Evidence of a two-fold glacial advance during the last glacial maximum in the Tagliamento end moraine system (eastern Alps). Quat Res 68(2):284-302

Moore PD, Webb JA, Collinson ME (1991) Pollen analysis, 2nd edn. Blackwell, Oxford

Müller-Beck H (2005a) Seeberg, Burgäschisee-Süd: Topographie und Stratigraphie. Acta Bernensia II, Teil 1. Stämpfli, Bern

Müller-Beck H (2005b) Seeberg, Burgäschisee-Süd: Bauten und Siedlungsgeschichte. Acta Bernensia II, Teil 2. Stämpfli, Bern

Nielsen E (2013) Response of the Lateglacial fauna to climatic change. Palaeogeogr, Palaeoclimatol, Palaeoecol 391(B):99-110

Pini R (2002) A high-resolution Late-glacial-Holocene pollen diagram from Pian di Gembro (Central Alps, Northern Italy). Veget Hist Archaeobot 11(4):251-262

Pini R, Ravazzi C, Aceti A, Castellano L, Perego R, Quirino T, Vallè F (2016) Ecological changes and human interaction in Valcamonica, the rock art valley, since the last deglaciation. AMQ 29(1):19-34

Ranalli P, Venturi G (2004) Hemp as a raw material for industrial applications. Euphytica 140:1-6

Reber R, Akçar N, Ivy-Ochs S, Tikhomirov D, Burkhalter R, Zahno C, Lüthold A, Kubik PW, Vockenhuber C, Schlüchter C (2014) Timing of retreat of the Reuss glacier (Switzerland) at the end of the last glacial maximum. Swiss J Geosci 107(2):293-307

Reille M (1992) Pollen et spores d'Europe et d'Afrique du Nord, Laboratoire de botanique historique et palynologie, Marseille

Reimer PJ, Bard E, Bayliss A, Beck JW, Blackwell PG, Bronk Ramsey C, Grootes PM, Guilderson TP, Haflidason H, Hajdas I, Hattž C, Heaton TJ, Hoffmann DL, Hogg AG, Hughen KA, Kaiser, KF, Kromer B, Manning SW, Niu M, Reimer RW, Richards DA, Scott EM, Southon JR, Staff RA, Turney CSM, van der Plicht J (2013) IntCal13 and Marine13 Radiocarbon Age Calibration Curves 0-50,000 Years cal BP. Radiocarbon 55(4):1869-1887

Rey F, Schwörer C, Gobet E, Colombaroli D, van Leeuwen JFN, Schleiss S, Tinner W (2013) Climatic and human impacts on mountain vegetation at Lauenensee (Bernese Alps, Switzerland) during the last 14,000 years. Holocene 23(10):1415-1427

Reuther A, Fiebig M, Ivy-Ochs S, Kubik PW, Reitner J, Jerz H, Heine K (2011) Deglaciation of a large piedmont lobe glacier in comparison with a small mountain glacier - new insight from surface exposure dating. Two studies from SE Germany. E\&G 60(2-3):248-269

Richoz I (1998) Etude paléoécologique du lac de Seedorf (Fribourg, Suisse). Histoire de la végétation et du milieu durant l'Holocène: le rôle de l'homme et du climat. Diss Bot 293:1-177

Robinson GS, Pigott Burney L, Burney DA (2005) Landscape paleoecology and megafaunal extinction in Southeastern New York State. Ecol Monogr 75(3):295-315 
Rösch M, Lechterbeck J (2016) Seven Millennia of human impact as reflected in high resolution pollen profile from the profundal sediments of Litzelsee, Lake Constance region, Germany. Veget Hist Archaeobot 25(4):339-358

Ruosch M, Spahni R, Joos F, Henne PD, van der Knaap WO, Tinner W (2016) Past and future evolution of Abies alba forests in Europe - comparison of a dynamic vegetation model with palaeo data and observations. Glob Chang Biol 22:727-740

Samartin S, Heiri O, Lotter AF, Tinner W (2012) Climate warming and vegetation response after Heinrich event 1 (16,700-16,000 cal yr BP) in Europe south of the Alps. Clim Past 8:1913-1927

Samartin S, Heiri O, Kaltenrieder P, Kühl N, Tinner W (2016) Reconstruction of full glacial environments and summer temperatures from Lago della Costa, a refugial site in Northern Italy. Quat Sci Rev 143:107-119

Schmid SM, Fügenschuh B, Kissling E, Schuster R (2004) Tectonic map and overall architecture of the Alpine orogen. Eclogae Geol Helv 97:93-117.

Smith HJ, Fischer H, Wahlen M, Mastroianni D, Deck B (1999) Dual modes of the carbon cycle since the Last Glacial Maximum. Nature 400:248-250

Stevens LR, Ito E, Olson DEL (2000) Relationship of Mn-carbonates in varved lake-sediments to catchment vegetation in Big Watab Lake, MN, USA. J Paleolimnol 24(2):199-211

Stöckli WE (2016) Urgeschichte der Schweiz im Überblick (15,000 v. Chr. - Christi Geburt) - Die Konstruktion einer Urgeschichte. Veröffentlichung der Archäologie Schweiz, Basel

Stockmarr J (1971) Tablets with spores used in absolute pollen analysis. Pollen Spores 13:615-621

Stuiver M, Polach HA (1977) Discussion: reporting of ${ }^{14} \mathrm{C}$ data. Radiocarbon 19(3):355-363

Stuiver M, Reimer P (1993) Extended ${ }^{14} \mathrm{C}$ data base and revised CALIB $3.0{ }^{14} \mathrm{C}$ age calibration program. Radiocarbon 35(1):215-230

Swierczynski T, Lauterbach S, Dulski P, Delgado J, Merz B, Brauer A (2013) Mid- to late Holocene flood frequency changes in the northeastern Alps as recorded in varved sediments of Lake Mondsee (Upper Austria). Quat Sci Rev 80(15):78-90

Tinner W, Hubschmid P, Wehrli M, Ammann B, Conedera M (1999) Long-term forest fire ecology and dynamics in southern Switzerland. J Ecol 87(2):273-289

Tinner W, Hu FS (2003) Size parameters, size-class distribution and area-number relationship of microscopic charcoal: relevance for fire reconstruction. Holocene 13(4):499-505

Tinner W, Lotter AF, Ammann B, Conedera M, Hubschmid P, van Leeuwen JFN, Wehrli M (2003) Climatic change and contemporaneous land-use phases north and south of the Alps 2300 BC to 800 AD. Quat Sci Rev 22:1447-1460

Tinner W, Conedera M, Ammann B, Lotter AF (2005) Fire ecology north and south of the Alps since the last ice age. Holocene 15(8):1214-1226

Tinner W, Lotter AF (2006) Holocene expansions of Fagus silvatica and Abies alba in Central Europe: where are we after eight decades of debate? Quat Sci Rev 25(5):526-549

Tinner W, Colombaroli D, Heiri O, Henne PD, Steinacher M, Untenecker J, Vescovi E, Allen JRM, Carraro G, Conedera M, Joos F, Lotter AF, Luterbacher J, Samartin S, Valsecchi V (2013) The past ecology of Abies alba provides new perspectives on future responses of silver fir forests to global warming. Ecol Monogr 83(4):419-439 
Van der Knaap WO, van Leeuwen JFN, Ammann B (2004) The first rise and fall of Fagus sylvatica and interactions with Abies alba at Faulenseemoos (Swiss Plateau) 6900-6000 cal yr BP. Acta Palaeobot 44(2):249-266

Van Geel B (2006) Fossil ascomycetes in Quaternary deposits. Nova Hedwigia 82(3-4):313-329

Van Raden UJ (2012) High-resolution Swiss lake records of climate change. Dissertation, ETH Zürich

Van Raden UJ, Colombaroli D, Gilli A, Schwander J, Bernasconi SM, van Leeuwen JFN, Leuenberger M, Eicher U (2013) High-resolution late-glacial chronology for the Gerzensee lake record (Switzerland): $\delta 180$ correlation between a Gerzensee-stack and NGRIP. Palaeogeogr, Palaeoclimatol, Palaeoecol 391(B):13-24

Vescovi E, Ravazzi C, Arpeti E, Finsinger W, Pini R, Valsecchi V, Wick L, Ammann B, Tinner W (2007) Interactions between climate and vegetation during the Lateglacial period as recorded by lake and mire sediment archives in Northern Italy and Southern Switzerland. Quat Sci Rev 26(11-12):1650-1669

Von Burg A, Hodel C, Bachmann A (2011) Paläolithikum und Mesolithikum. In: Hodel C, von Burg A, Marti R, Bachmann A (eds) Archäologie des Oberaargaus - Ur- und Frühgeschichte 13,000 v. Chr. bis 700 n. Chr. Sonderband 6. Jahrbuch des Oberaargaus, pp 13-29

Wanner H, Beer J, Bütikofer J, Crowley TJ, Cubasch U, Flückiger J, Goosse H, Grosjean M, Joos F, Kaplan JO, Küttel M, Simon A. Müller SA, Prentice IC, Solomina O, Stocker TF, Tarasov P, Wagner M, Widmann M (2008) Mid- to Late Holocene climate change: An overview. Quat Sci Rev 27(19-20):1791-1828

Wehrli M, Tinner W, Ammann B (2007) 16,000 years of vegetation and settlement history from Egelsee (Menzingen, central Switzerland). Holocene 17(6):747-761

Welten M (1944) Pollenanalytische, stratigraphische und geochronologische Untersuchungen aus dem Faulenseemoos bei Spiez. Veröffentlichungen des Geobotanischen Instituts Rübel, Zürich 21:1-201

Welten M (1946) Pollenprofil Burgäschisee. Ein Standard-Diagramm aus dem solothurnisch-bernischen Mittelland. Bericht über das Geobotanische Forschungsinstitut Rübel, Zürich, pp 101-111

Welten M (1955) Pollenanalytische Untersuchungen über die neolithischen Siedlungsverhältnisse am Burgäschisee. Vorläufige Ergebnisse. In: Guyan W, Walter U (eds) Das Pfahlbauproblem. Birkhäuser, Basel, pp 61-88

Welten M (1967) Bemerkungen zur paläobotanischen Untersuchung von vorgeschichtlichen Feuchtbodenwohnplätzen und Ergänzungen zur pollenanalytischen Untersuchung von BurgäschiseeSüd. In: Bandi HG, Müller-Beck H (eds) Seeberg Burgäschisee-Süd. Teil 4: Chronologie und Umwelt. Acta Bernensia II. Stämpfli, Bern, pp 9-20

Welten M (1982) Vegetationsgeschichtliche Untersuchungen in den westlichen Schweizer Alpen: BernWallis. Denkschr Schweiz Natforsch Ges 95:1-104

Wetzel RG (2001) Limnology: Lake and river ecosystems. $3^{\text {rd }}$ edn. Elsevier Science, USA

Wey O (2012) Die Cortaillod-Kultur am Burgäschisee: Materialvorlage und Synthese zu den neolithischen Fundkomplexen von Burgäschisee-Ost, -Südwest, -Süd und -Nord. Stämpfli, Bern

Wick L (1996) Late-glacial and early-Holocene palaeoenvironments in Brianza, N Italy. Il Quaternario 9:653-660

Wick (2000) Vegetational response to climatic changes recorded in Swiss Late Glacial lake sediments. Palaeogeogr, Palaeoclimatol, Palaeoecol 159(3-4):231-250 
Wirsig C, Zasadni J, Christl M, Akçar N, Ivy-Ochs S (2016) Dating the onset of LGM ice surface lowering in the High Alps. Quat Sci Rev 143:37-50

Wyss R (1952) Fürsteiner-Seeberg, eine spätjungpaläolithische Freilandstation. Jahrb Schweiz Ges für Urgesch 42:133-154

Wyss R (1953) Beiträge zur Typologie der Paläolithisch-Mesolithischen Übergangsformen im Schweizerischen Mittelland. Schriften des Institutes für Ur- und Frühgeschichte der Schweiz, Basel

Zolitschka B (1998) A 14,000 year sediment yield record from western Germany based on annually laminated lake sediments. Geomorphology 22(1):1-17 


\section{Table and figure captions}

Table 1 Radiocarbon dates and calibrated ages from the Burgäschisee record

Table 2 Oldest radiocarbon dates in sediment sequences from lowland regions around the Alps

Fig. 1 Overview map (top left) with the location of the Swiss Plateau (yellow area), Burgäschisee (*) and study sites for oldest radiocarbon dates in sediment records: 1 Wauwilermoos (Beckmann 2004), 2 Rotsee (Lotter and Zbinden 1989), 3 Soppensee (Lotter 1999), 4 Lago Piccolo di Avigliana (Larocque and Finsinger 2008), 5 Lago di Origlio (Tinner et al. 1999). Photograph of Burgäschisee (top right). Seismic map of the study site with the coring location (bottom). Green areas around the lake $=$ forests, green empty circles $=$ single trees (topographic maps: (C) swisstopo)

Fig. 2 Age-depth-model and lithology of Burgäschisee. Black dots show calibrated ages of terrestrial plant macrofossils with $2 \sigma$ error bars (IntCal13, Reimer et al. 2013). The black line is the modelled chronology (Smooth spline 0.23 with the program clam 2.2, Blaauw 2010). The grey lines indicate the 95\% confidence envelope of the generalized mixed effect regression (GAM, Heegaard et al. 2005)

Fig. 3 Percentages of selected pollen types, fern spores and coprophilous fungal spores and charcoal influx values of Burgäschisee. Empty curves are the 10x exaggerations. LPAZ = local pollen assemblage zones. LST = Laacher See tephra (dashed line). Light grey bar = Younger Dryas (van Raden et al. 2013)

Fig. 4 Composite of lithology, loss on ignition at $550^{\circ} \mathrm{C}$ (LOI 550) and $950^{\circ} \mathrm{C}$ (LOI 950), XRF counts of selected elements per area $(0.2 \times 12 \mathrm{~mm}$, van Raden 2012) (left part). The grey lines of the XRF data show the original counts, the black lines are the moving averages (period $=19$ ). Pollen percentages of selected pollen types, pollen concentrations $\left(\right.$ particles $/ \mathrm{cm}^{3}$ ) of herbs, shrubs and trees, pollen influx (particels $/ \mathrm{cm}^{2} \mathrm{yr}$ ) of herbs, shrubs and trees, microscopic charcoal concentrations and microscopic 
charcoal influx (right part). Empty curves are the 10x exaggerations. LPAZ $=$ local pollen assemblage zones. LST = Laacher See tephra (dashed line). Light grey bar = Younger Dryas (van Raden et al. 2013)

Fig. 5 Pollen analysis of seven consecutive sediment layers (5 light layers and 4 dark layers) from $333.6-332.5 \mathrm{~cm}$. The selected pollen types are ordered by the timing of their general blooming (Lauber et al. 2014)

Fig. 6 XRF curves showing the correlation of $\mathrm{Mn}$ and $\mathrm{Ca}$ and the occurrence of sporadic Ti-rich (erosional) layers from $333.2-327.2 \mathrm{~cm}$. The y-axes represent the concentrations for each element (van Raden 2012, modified) 


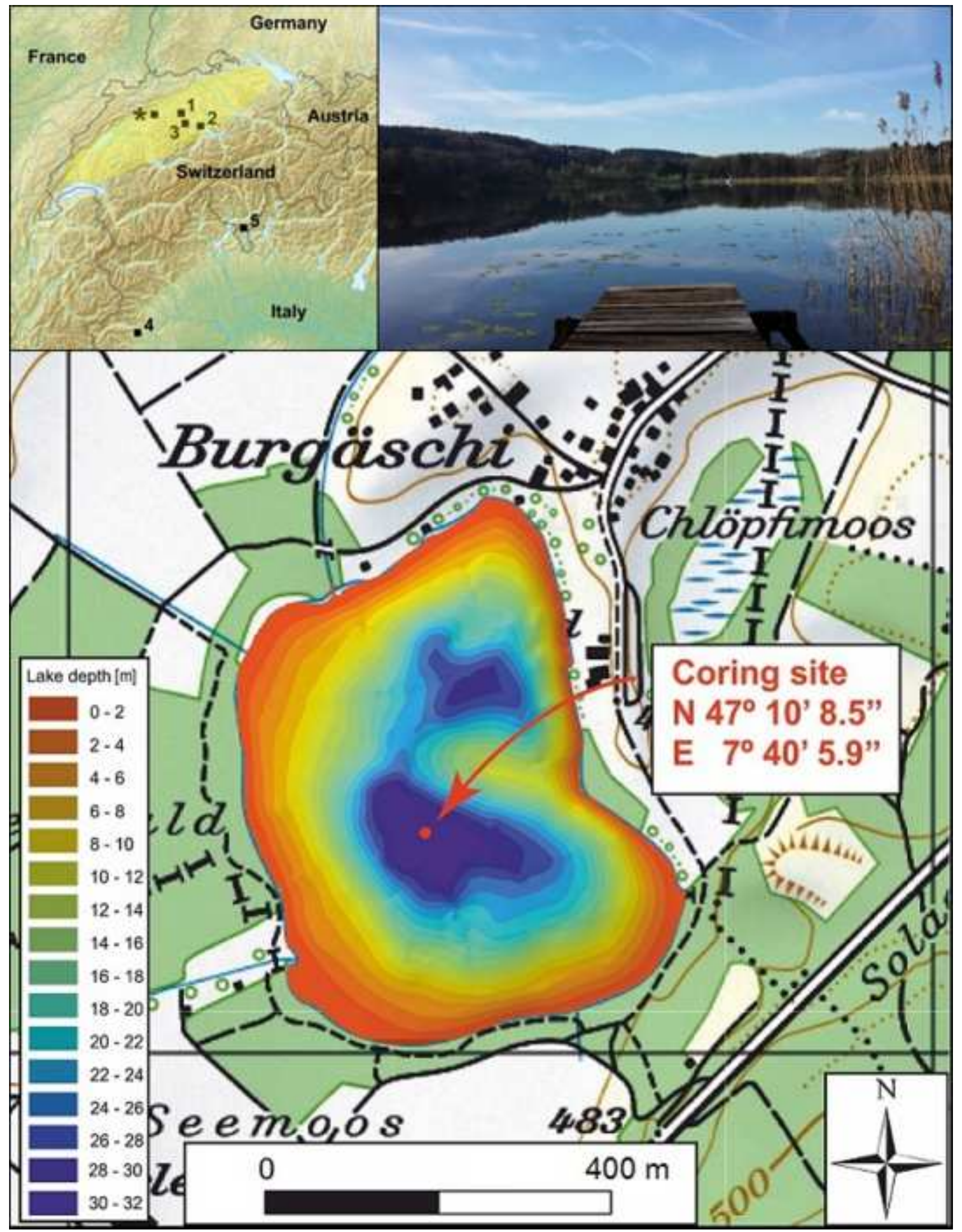




\section{Age [cal B.P.]}

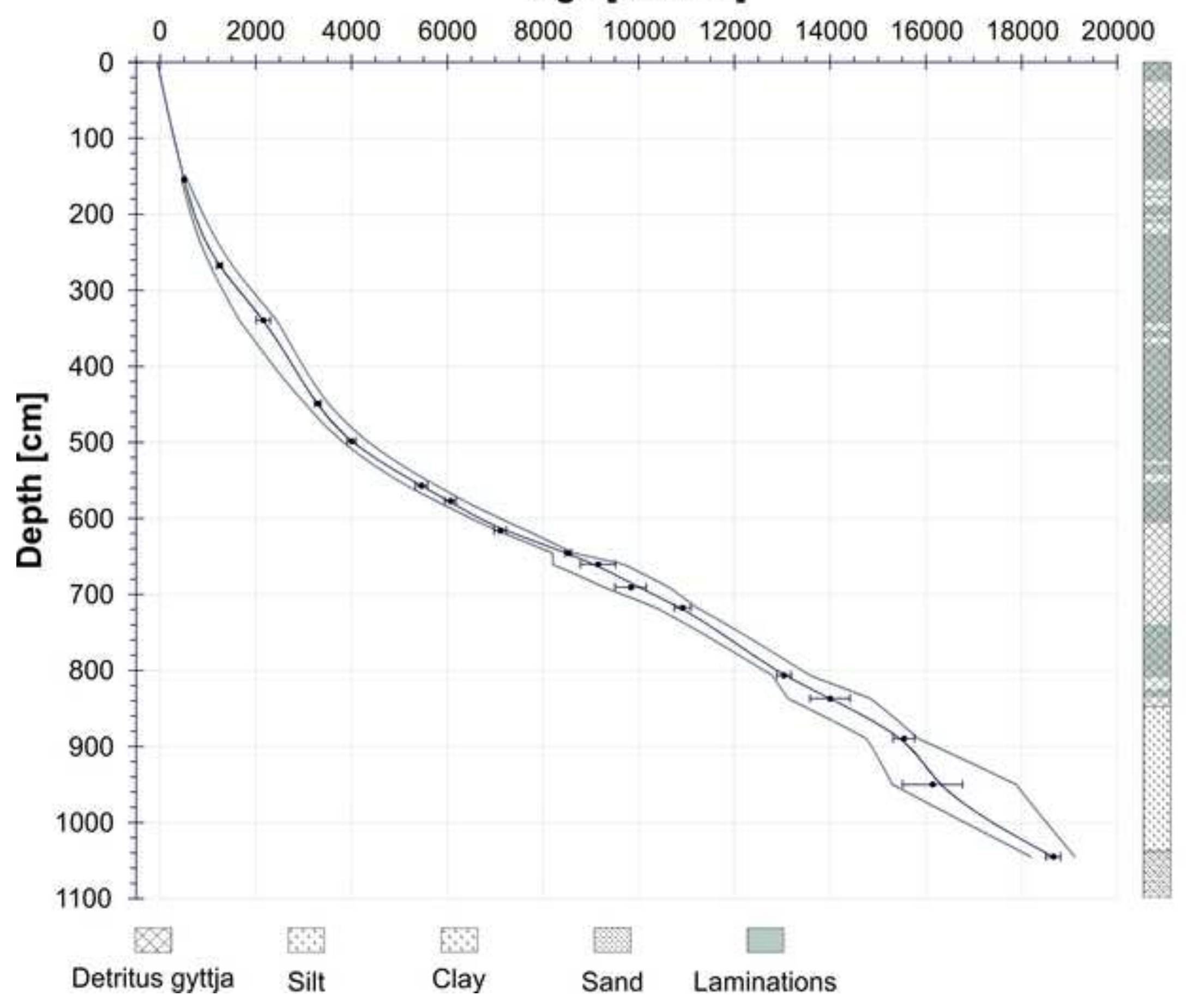




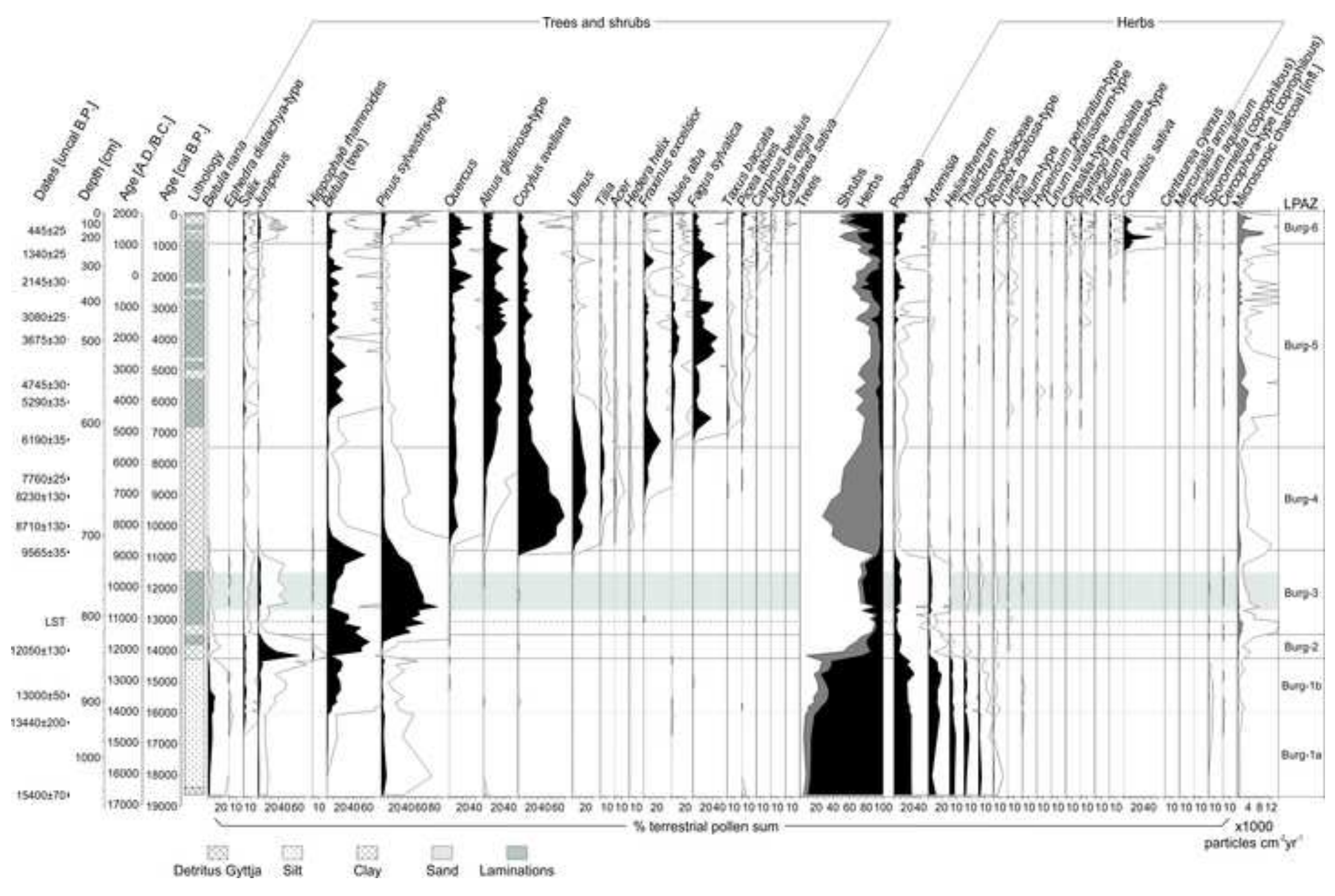




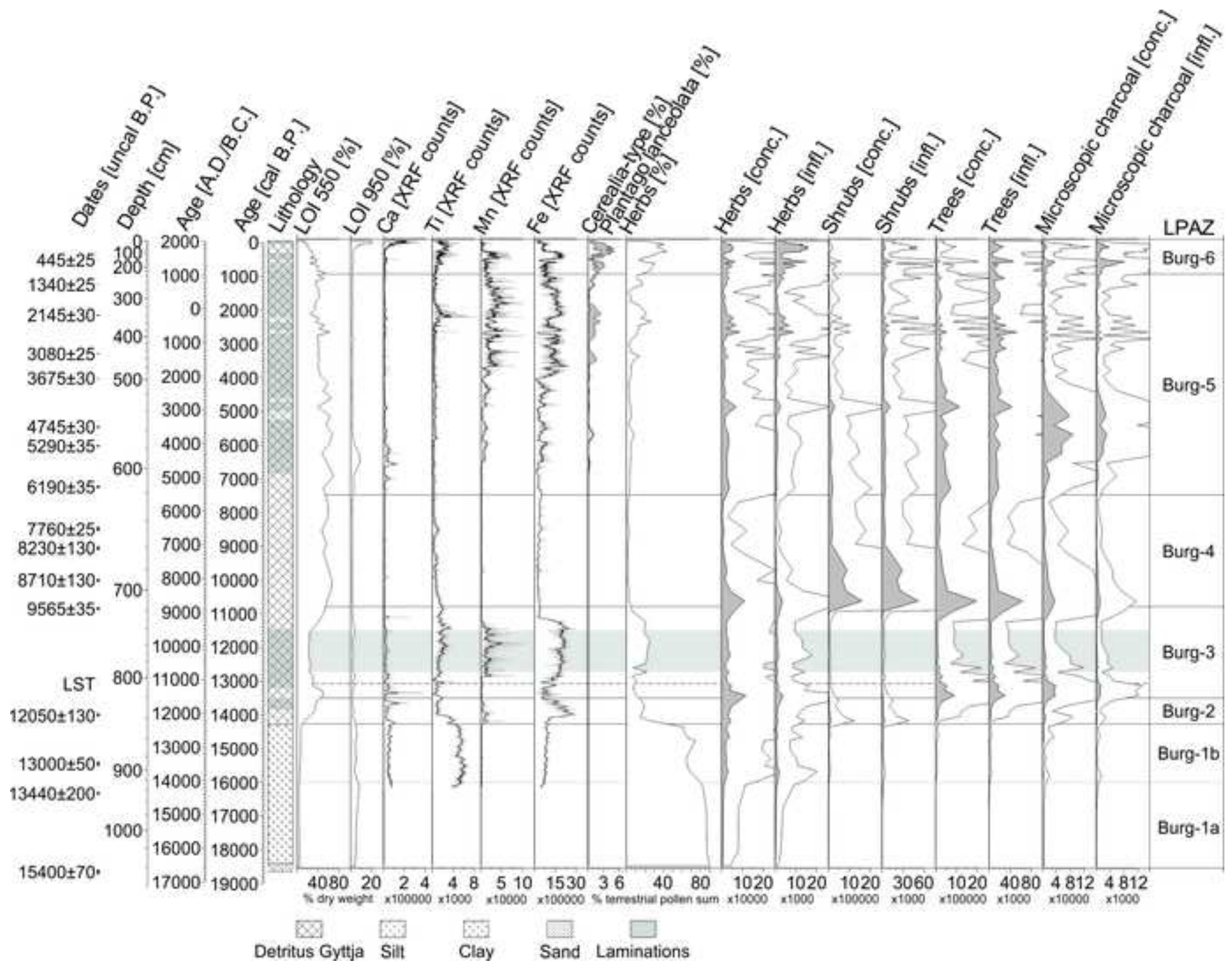




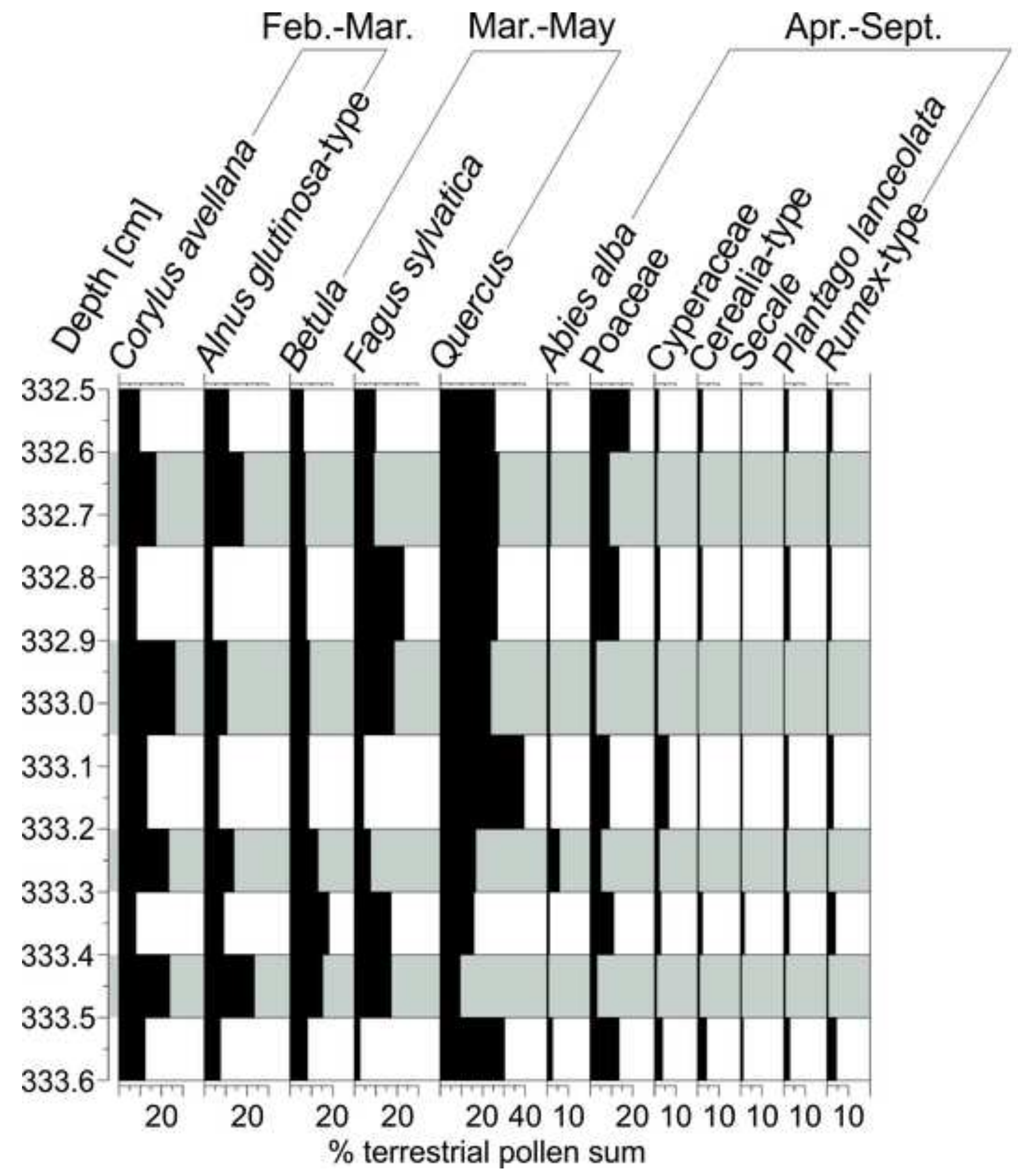




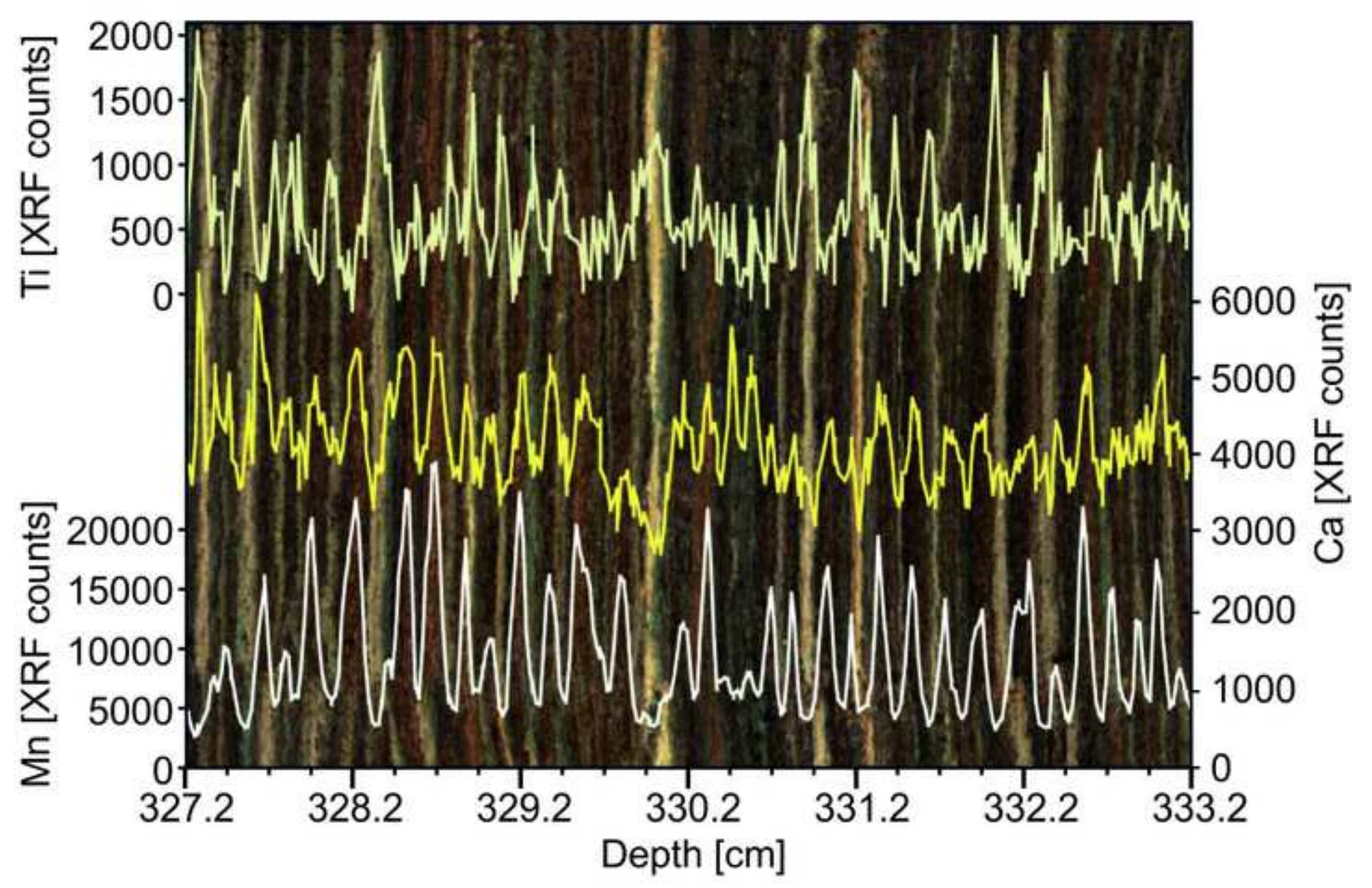




\begin{tabular}{|c|c|c|c|c|c|c|}
\hline Lab. code & Depth $[\mathrm{cm}]$ & Material & $\begin{array}{l}{ }^{14} \mathrm{C} \text { age } \\
{[\text { B.P. }]^{\mathrm{a}}}\end{array}$ & $\begin{array}{l}\text { Age } \\
\text { [cal B.P.] }^{\text {b }}\end{array}$ & $\begin{array}{l}\text { Age } 2 \sigma \text { range } \\
{\text { [cal B.P. }]^{\mathrm{b}}}\end{array}$ & $\begin{array}{l}\text { Modelled age } \\
\text { [cal B.P.] }^{\mathrm{c}}\end{array}$ \\
\hline ETH-43940 & 154 & Deciduous tree leaf & $445 \pm 25$ & 504 & $479-529$ & 503 \\
\hline ETH-43941 ${ }^{\mathrm{e}}$ & $267-268$ & Deciduous tree leaf & $1,340 \pm 25$ & 1,245 & $1,187-1,303$ & 1,250 \\
\hline ETH- $43942^{\mathrm{e}}$ & $338-341$ & Betula leaf & $2,145 \pm 30$ & 2,156 & $2,008-2,303$ & 2,148 \\
\hline ETH- $43943^{\mathrm{e}}$ & $448-450$ & $\begin{array}{l}\text { Betula leaf, Fagus syvatica } \\
\text { bud scale }\end{array}$ & $3,080 \pm 25$ & 3,294 & $3,225-3,363$ & 3,287 \\
\hline ETH-43944 & $498-499$ & Abies alba needle & $3,675 \pm 30$ & 3,999 & $3,908-4,089$ & 4,013 \\
\hline ETH-43945 & $556-558$ & $\begin{array}{l}\text { Betula leaf, bud scale } \\
\text { deciduous }\end{array}$ & $4,745 \pm 30$ & 5,457 & $5,330-5,584$ & 5,458 \\
\hline ETH-43946 & $576-578$ & Betula leaf & $5,290 \pm 35$ & 6,066 & $5,948-6,184$ & 6,019 \\
\hline ETH- $43947^{\mathrm{e}}$ & $615-617$ & Betula fruit, leaf fragments & $6,190 \pm 35$ & 7,108 & $6,978-7,237$ & 7,232 \\
\hline BE-2549.1.1 ${ }^{\mathrm{f}}$ & $644-647$ & Leaf fragments & $7,760 \pm 25$ & 8,525 & $8,456-8,593$ & 8,480 \\
\hline BE-2550.1.1 ${ }^{\mathrm{f}}$ & $659-662$ & $\begin{array}{l}\text { Betula fruit, anthers, leaf } \\
\text { fragment }\end{array}$ & $8,230 \pm 130$ & 9,148 & $8,780-9,516$ & 9,052 \\
\hline BE-2551.1. ${ }^{\mathrm{f}}$ & $689-692$ & Betula fruit scales & $8,710 \pm 130$ & 9,832 & $9,504-10,160$ & 10,008 \\
\hline \multirow[t]{2}{*}{ ETH- $43948^{e}$} & $716-719$ & $\begin{array}{l}\text { Pinus sylvestris short shoot, } \\
\text { Pinus sylvestris needles, } \\
\text { Pinus sylvestris bud scale, } \\
\text { leaf fragments }\end{array}$ & $9,565 \pm 35$ & 10,915 & $10,739-11,090$ & 10,846 \\
\hline & 806.5 & Laacher See Tephra (LST) & & $13,034^{\mathrm{d}}$ & $12,884-13,184^{\mathrm{d}}$ & 13,071 \\
\hline $\mathrm{BE}-2552.1 .1^{\mathrm{f}}$ & $835.5-838.5$ & $\begin{array}{l}\text { Betula fruits, Betula fruit } \\
\text { scale }\end{array}$ & $12,050 \pm 130$ & 13,997 & $13,579-14,414$ & 13,997 \\
\hline ETH- $43949^{\mathrm{e}}$ & $886.5-892.5$ & $\begin{array}{l}\text { Betula nana fruit scales, } \\
\text { Betula nana fruits, periderm } \\
\text { deciduous, leaf fragments } \\
\text { deciduous, bud scales } \\
\text { deciduous, twiglet, bark }\end{array}$ & $13,000 \pm 50$ & 15,540 & $15,316-15,764$ & 15,447 \\
\hline BE-2553.1.1 ${ }^{\mathrm{f}}$ & $947.5-952.5$ & Twiglet & $13,440 \pm 200$ & 16,140 & $15,512-16,767$ & 16,321 \\
\hline Poz-60131 & $1,042.5-1,047.5$ & Twiglet & $15,400 \pm 70$ & 18,665 & $18,512-18,817$ & 18,650 \\
\hline
\end{tabular}

\footnotetext{
${ }^{\mathrm{a}}$ Stuiver and Polach (1977)

${ }^{\text {b }}$ Stuiver and Reimer (1993); Reimer et al. (2013)

${ }^{\mathrm{c}}$ Blaauw (2010)

${ }^{\mathrm{d}}$ Van Raden et al. (2013)

${ }^{\mathrm{e}}$ Laboratory of Ion Beam Physics, ETH Zurich, Switzerland

${ }^{\mathrm{f}}$ Laboratory for the Analysis of Radiocarbon, Bern University, Switzerland

g Poznan Radiocarbon Laboratory, Poland
} 


\begin{tabular}{|c|c|c|c|c|c|c|c|}
\hline Site name & $\begin{array}{l}\text { Altitude } \\
\text { [m a.s.1.] }\end{array}$ & Reference & ${ }^{14} \mathrm{C}$ age [B.P.] ${ }^{\mathrm{a}}$ & $\begin{array}{l}\text { Age } \\
\text { [cal B.P.] }\end{array}$ & $\begin{array}{l}\text { Age } 2 \sigma \text { range } \\
\text { [cal B.P.] }\end{array}$ & $\begin{array}{l}\text { Depth } \\
{[\mathrm{cm}]}\end{array}$ & $\begin{array}{l}\text { Total core } \\
\text { length }[\mathrm{cm}]\end{array}$ \\
\hline Burgäschisee & 465 & & $15,400 \pm 70$ & 18,665 & $18,512-18,817$ & 1045 & 1500 \\
\hline Wauwilermoos & 500 & Beckmann 2004 & $15,300 \pm 130$ & 18,548 & $18,263-18,832$ & 690 & c. 795 \\
\hline Rotsee & 419 & Lotter and Zbinden 1989 & $14,600 \pm 200$ & 17,764 & $17,254-18,274$ & 915 & c. 1250 \\
\hline Soppensee & 595 & Lotter et al. 1997; Lotter 1999 & $14,200 \pm 120$ & 17,272 & $16,917-17,627$ & 680 & c. 800 \\
\hline Lago Piccolo di Avigliana & 365 & Larocque and Finsinger 2008 & $14,900 \pm 80$ & 18,120 & $17,902-18,337$ & 909 & c. 1490 \\
\hline Lago di Origlio & 419 & Tinner et al. 1999 & $14,500 \pm 80$ & 17,684 & $17,453-17,915$ & 1398 & 1955 \\
\hline
\end{tabular}

${ }^{\text {a }}$ Stuiver and Pollach (1977)

${ }^{\text {b }}$ Stuiver and Reimer (1993); Reimer et al. (2013) 